Canadian

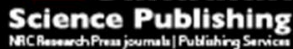

Canadian Geotechnical Journal Revue canadienne de géotechnique

\title{
Shear bands in undrained plane strain compression of Norwegian quick clays
}

\begin{tabular}{|r|l|}
\hline Journal: & Canadian Geotechnical Journal \\
\hline Manuscript ID & cgj-2016-0443.R2 \\
\hline Manuscript Type: & Article \\
\hline Date Submitted by the Author: & 31 -May-2017 \\
\hline Complete List of Authors: & $\begin{array}{l}\text { Thakur, Vikas; Norwegian University of Science and Technology, Civil and } \\
\text { Environmental Engineering } \\
\text { Nordal, S.; Norwegian University of Science and Technology, Civil and } \\
\text { Environmental Engineering } \\
\text { Viggiani, Gioacchino; Universite Grenoble Alpes } \\
\text { Charrier, Pascal; Universite Grenoble Alpes, L3S-R }\end{array}$ \\
\hline Keyword: & $\begin{array}{l}\text { plane strain testing, sensitive clay, strain localization, shear band, Digital } \\
\text { Image Correlation }\end{array}$ \\
\hline &
\end{tabular}




\title{
Shear bands in undrained plane strain compression of Norwegian quick clays
}

\author{
Vikas Thakur ${ }^{1}$, Steinar Nordal $^{2}$, Gioacchino Viggiani $^{3}$, and Pascal Charrier ${ }^{4}$
}

${ }^{1}$ Vikas.Thakur@ntnu.no, Norwegian University of Science and Technology, Norway, Phone:

+47412957 17, Fax: +47 73594609

2 Steinar.Nordal@,ntnu.no, Norwegian University of Science and Technology (NTNU), Trondheim, Norway, Phone: +47 735945 95, Fax: +47 73594609

${ }^{3}$ Cino.Viggiani@3sr-grenoble.fr, Univ. Grenoble Alpes, CNRS, Grenoble INP*, 3SR, F38000 Grenoble, France

${ }^{4}$ Pascal.Charrier@3sr-grenoble.fr, Univ. Grenoble Alpes, CNRS, Grenoble INP*, 3SR, F38000 Grenoble, France

* Institute of Engineering Univ. Grenoble Alpes 


\title{
Shear bands in undrained plane strain compression of Norwegian quick clays
}

\begin{abstract}
This work presents the results of plane strain tests carried out at the Laboratoire 3SR Grenoble (France) on undisturbed samples of very sensitive Norwegian soft clay. The discussion of the results focuses on the observed failure mechanisms and zones of localized deformation. The tested clay is defined as quick clay because it liquefies completely upon remolding. Thus, careful handling was necessary, and original procedures were developed to place samples in the plane strain testing device with minimum disturbance. The results show that excess pore water pressure develops during shear loading and shear strength is lost after the peak, which is a typical phenomenon in sensitive soils. The sample is held between two glass plates to enable visual tracking of the deformations. A digital image correlation analysis reveals a complex pattern of emerging shear bands, with one or two bands dominating and providing a final failure mechanism. Two local pore water pressure transducers are attached to the sample boundary and show differences in local excess pore water pressure. It is suggested that excess pore water pressure depends on the distance from the transducers to the zones of concentrated shear strains.
\end{abstract}

Keywords: plane-strain testing, sensitive soft clay, strain localization, shear band, local pore water pressure measurements, Digital Image Correlations 


\section{Introduction}

Sensitive, or quick, clays found in Scandinavia are highly susceptible to liquefaction upon shear loading beyond peak strength (Bjerrum 1955; Janbu 1979; Karlsrud et al. 1985; Thakur and Degago 2012,2013; Thakur et al. 2014). This implies that even a modest triggering event may result in devastating landslides, such as the Rissa landslide (Gregersen 1981), the Kattmarka landslides (Nordal et al. 2009), and the Byneset flow slide (Thakur et al. 2014). Determining the strength and stability of quick clay is therefore an essential task for Scandinavian geotechnical researchers (e.g., Bjerrum 1955; Janbu 1967; Karlsrud and Hernandez-Martinez 2013; Thakur et al. 2012, 2014; Amundsen et al. 2015,2016). Unfortunately, stability evaluations using classical limit equilibrium (LE) methods exhibit shortcomings when applied to a strain-softening material (e.g., Bernander 2000; Jostad and Andresen 2002; Jostad et al. 2006; Thakur 2007; Gylland et al. 2010; Jostad et al. 2014). The main shortcoming of LE methods is that peak strengths are considered along a potential shear surface. However, in reality, some soil along the shear surface may have undergone softening and lost strength even though peak shear strength has not been attained at other points on the surface. Progressive failure mechanisms must be considered (e.g., Andresen and Jostad 2007; Gylland et al. 2013; Thakur 2011; Grimstad and Jostad 2012). For Scandinavian quick clays, this involves modeling the strain softening behavior, including progressive propagation of localized failure along a shear band, which defines the slip surface. Most shear bands associated with slope failures develop under conditions very close to plane strain. However, to the best of the authors' knowledge, no plane strain tests have been performed on Norwegian quick clays; they have always been tested under more conventional triaxial conditions.

This paper presents the results of a comprehensive laboratory testing program specifically designed to study the formation of shear bands in Norwegian quick clays under plane strain 
conditions. Mechanisms for the formation and propagation of shear bands in Norwegian quick clays are studied using digital image correlation. Local pore water pressure (pwp) transducers are also used to determine whether localized deformation is accompanied by non-uniformities of excess pwp.

\section{Background}

\section{General aspects of quick clays}

During the last glaciation, marine clays were formed in Scandinavia. When the ice disappeared, the land rose, and over the next 10.000 years, sodium chloride was leached from the marine clays (Rosenqvist 1953). Large amounts of marine clays became "quick" clays, which are defined in Norway as sensitive clays with remolded shear strength of less than 0.5 $\mathrm{kPa}$. Quick clays' natural water content $(w)$ is higher than their liquid limit $\left(w_{L}\right)$. Norwegian quick clays are brittle and have a plasticity index of less than $10 \%$. Thakur and Degago $(2012,2014)$, Thakur et al. $(2013,2014)$ have demonstrated that remolded quick clay behave as a viscous fluid rather than a plastic solid.

Quick clays are typically classified according to their sensitivity $\left(S_{t}\right)$, which is the ratio of the intact shear strength $\left(c_{u i}\right)$ to the corresponding remolded shear strength $\left(c_{u r}\right)$ according to the results of fall cone tests performed with the same water content. Several classification systems have been proposed in the literature (Skempton and Northey 1952; Rosenqvist 1953; Norwegian Geotechnical Society [NGF] 1974). These classifications are presented in Table 1.

\section{Undrained behavior of quick clays in triaxial compression}

Quick clays in Scandinavia are soft and very sensitive to disturbance during sampling. Fig. 1 shows the results of conventional undrained triaxial compression tests on Tiller quick clay using two different samplers with diameters of 54 and $160 \mathrm{~mm}$. Despite the fact that both 
samplers were used carefully, higher peak strength was found in the sample obtained from the larger sampler. Sample disturbance also affects pre-consolidation pressure, which is measured by oedometer tests and shown in Fig. 1. The high-quality 160 -mm-diameter block sample had higher pre-consolidation pressure than the 54-mm-diameter sample. Lacasse et al. (1985) and Lunne et al. (1997) suggested that sample disturbance causes partial microstructure collapse prior to loading. Quick clay samples exhibit strain softening when sheared in undrained conditions. In line with the contractive behavior exhibited by quick clays in these conditions, positive excess pwp is generated by undrained compression. This is evidenced by the effective stress path presented in Fig. 1. Minimal sample disturbances result in lower pwp build-up prior to failure and higher pwp during strain softening. Interestingly, the effective strength parameters, such as the cohesion $(c)$ and friction angle $(\varphi)$ at failure, are unique to the tested material regardless of sample disturbance. The results of a triaxial test of six different soft sensitive clays performed by Thakur et al. (2014) shows that undrained soft sensitive clays exhibit strain softening due to shear-induced pwp, not cohesion and friction softening, at strain levels of $10-20 \%$. However, at very high strain levels, cohesion and friction softening may occur.

\section{Stability of quick clay slopes in undrained conditions}

Rapid deviatoric loading beyond the peak leads to pwp build-up in quick clays. In a zone of concentrated shear deformation, pwp will increase in line with shear deformations. However, if failure does not occur immediately, the pwp will decrease with time and increased effective stresses and shear stress capacity in the band. Two counterbalancing mechanisms can be observed: increasing shear deformations will increase local pwp, and local drainage will reduce pwp (Fig. 2). The rate of loading and the material response to stress change according to the pwp inside and outside the shear band, and this will control the process of failure in the 
material (Bernander 2002; Thakur et al. 2005; Jostad et al. 2006; Thakur 2011; Gylland et al. 2012; Jostad et al. 2014). In the current paper, this behavior is studied experimentally using plane strain tests with appropriate loading rates under globally undrained conditions.

\section{Literature review of studies involving plane strain testing of fine- grained materials}

In recent decades, many experimental studies have examined strain localization in a variety of geomaterials, including rock, sandstone, sand, stiff clays, and soft clays. The formation and orientation of shear bands in sand is comprehensively discussed by Desrues and Viggiani (2004) and the several studies cited therein. Finno and Rhee (1992), Viggiani et al. (1994), Lizcano et al. (1997), Viggiani et al. (2001), Chen (2004), Yuan et al. (2013), and Gylland et al. (2014) confirm that shear banding may take place in both contractive and dilative clay specimens, but in the latter, the onset of localization is delayed until cavitation occurs in the pore fluid.

Only a few experimental studies have conducted plane strain compression testing of soft clays (e.g., Topolnicki et al. 1990; Finno and Rhee 1992; Lizcano et al. 1997; Cheng 2004; Yuan et al. 2013). Most of these studies have focused on shear band thickness, local dilatancy angle, void ratio near the shear band, and orientation of the shear band. A recent study by Yuan et al. (2013) investigating two medium plastic silty clays measures the dilatancy of the shear bands and local pwp near these bands and further away.

Viggiani et al. (1994) studied the formation of shear bands in stiff clays in an undrained plane strain compression apparatus. Marello (2005) also investigated the propagation and formation of shear bands in stiff clays using a plane strain compression apparatus. The false relief stereo photogrammetry technique was used for image correlation in both studies. They also report 
local changes in pwp within the specimen at the onset of localization. However, local changes in pwp were not registered after the onset of localization because of local drainage of pwp within the clay specimen.

Cheng (2004) studied the formation and propagation of cracks in organic clays. Three different strain rates are applied: $0.5 \mathrm{~mm} / \mathrm{hr}, 1 \mathrm{~mm} / \mathrm{hr}$, and $5 \mathrm{~mm} / \mathrm{hr}$. The tests result in the formation of cracks near the top plate. Pwp is measured at the center of the ends of specimens. Cheng concludes that soft organic clays exhibit strong discontinuity, exhibited as cracks or interfaces rather than shear bands.

Gylland et al. (2014) performed an experimental investigation of the formation and propagation of shear bands in Norwegian sensitive clay using a modified triaxial cell that allows for shear band formation. They study the effect of various displacement rates on the onset of strain localization and on the softening response of the tested material. Reduced shear band thickness and shear band inclination approaching $45^{\circ}$ were observed in response to increasing displacement rates.

Mitchell and Wang (1973) and Boudali (1995) conducted a series of true triaxial tests on two different Canadian sensitive clays. Boudali (1995) examined the effect of intermediate principal stresses on the strength of Louiseville clay. Mitchell and Wong (1973) conducted several plane strain tests on samples of Ottawa Valley Champlain sea clay. These tests were conducted under drained conditions at low confining pressure. Either of these studies make no discussion on the formation and propagation of shear band. 


\section{Laboratory experiments}

\section{Material tested: Tiller quick clay}

The quick clay chosen for this study was sampled from Tiller, located approximately $10 \mathrm{~km}$ southeast of Trondheim, Norway. The area is covered by a quick clay deposit approximately $10 \mathrm{~m}$ in depth, which in turn is covered by a silty, low-sensitivity marine clay. The samples used in this study were carefully recovered from two different bore locations at depths of 6$10 \mathrm{~m}$ using a 95-mm piston sampler with a steel cylinder. Routine characterization and index tests were performed, and the results are summarized in Table 2. It should be emphasized that the Tiller quick clay deposit covers a large area; thus, variations in the soil properties (both laterally and vertically) should be expected in the table. The oedometer tests performed by Gylland et al. (2013) and Amundsen et al. (2017) suggest that the overconsolidation ratio of the quick clay deposit varies from 1.3 to 1.6 and the effective earth pressure coefficient at rest $\left(K_{o}{ }^{\prime}\right)$ is 0.6 . A low-sensitivity soft clay specimen (T6) was also tested. This sample was taken from the same area, but its sensitivity and remolded shear strength were 20 and $1.5 \mathrm{kPa}$, respectively. Thus, it is not a quick clay, although it is still sensitive.

\section{The plane strain apparatus}

The plane strain apparatus at Laboratoire $3 \mathrm{SR}$ was originally developed in Grenoble by Desrues (1984) and was later modified by Hammad (1991). The device is similar to those developed by Vardoulakis and Goldscheider (1981) and Drescher et al. (1990) in that the apparatus is specifically designed to allow free shear-band formation in a soil specimen. The top plate is free to slide horizontally (but not rotate) within the plane of deformation. The lower and upper loading plates house porous stones connected to drainage lines. A large cell filled with silicone oil surrounds the specimen and can sustain up to $2 \mathrm{MPa}$. Two opposing 
pairs of 50-mm-thick glass plate windows laterally support the sample and create the plane strain conditions. Strain-controlled axial loading is applied by a screw jack that rests atop the device. An LVDT measures the vertical deformation of the sample, while an internal load cell at the top of the device measures axial load. Cell pressure is supplied by a compressor and monitored by a pressure transducer, while a self-compensating mercury control is used to apply backpressure to the cell oil and pore water. The output signals of all transducers are conditioned by a process interface unit, which is linked to a microcomputer controlling all operations (Desrues and Viggiani 2004).

A 34-mm-thick prismatic specimen surrounded by a latex membrane is mounted between two rigid glass plates to create the plane strain conditions. In this study, the initial height and width of the specimen (in the plane of deformation) are $120 \mathrm{~mm}$ and $60 \mathrm{~mm}$, respectively. The sidewalls allow photographs to document the in-plane deformation of a specimen during the test. The glass surfaces that will be in contact with the specimen are lubricated with silicone grease to minimize friction. The plane strain apparatus is shown in Fig. 3. Further details regarding the apparatus and testing procedure can be found in Desrues and Viggiani's (2004) study and the references cited therein.

\section{Specimen preparation and instrumentation}

Large specimens (120 mm x $60 \mathrm{~mm}$ x $34 \mathrm{~mm})$ were carefully cut from the 95-mm-diameter samples. Although the standard sampler size in Norway is $54 \mathrm{~mm}$, a 95-mm sampler was used in this study to achieve higher-quality samples, in line with Lacasse et al. (1985) and Lunne et al. (2007). A block sampler was not available. To avoid disturbing the sensitive quick clay specimens, a special method for mounting the specimens in the plane strain apparatus had to be developed. A splitting- and sliding-type stainless steel mold was prepared to place the 
specimen on a stretched latex membrane. The inner mold holds the specimen, while the outer shell stretches the membrane, which allows for minimum disturbance. This process is explained by a set of photographs in Fig. 4 .

Once the specimen is placed inside the membrane, two temporary supports are attached to it. These supports were needed to transfer loads (such as self-weight and external forces) directly from the top plate to the bottom plate without damaging the quick clay sample while fixing the top plates, connecting the drainage lines, and inserting the pwp transducers. The supports were removed only after the specimen was completely mounted in the apparatus. O-rings were used to seal the point of contact between the membrane and the top and bottom plates. Fig. 4 shows the two vertical supports that connect the top and bottom plates. A typical set up of the specimen is presented in Fig. 5.

The present study investigates pwp-induced softening in shear bands. To do so, miniature pwp transducers are used to measure local pwp (Fig 5). The miniature pwp probes were calibrated to capture small fluctuations in pwp following a procedure suggested by Hight (1982). Unfortunately, pwp could not be measured simultaneously at the top and bottom of the sample due to equipment restrictions. The two miniature probes were mounted on the surface of the specimen in two different layouts: 1) midway up the specimen (60 $\mathrm{mm}$ from the top) on the left and right side (LP and RP, respectively) of the sample or 2) both on the same side of the specimen, one midway up the specimen (CP) and the other at one-quarter of the height (30 $\mathrm{mm}$ ) from the top (TP) or bottom (BP). The location of the probes was chosen based on the assumed positions of potential shear bands in order to determine whether pwp increases more near an emerging and propagating shear band. The probes were carefully placed on the surface of the specimen to avoid disturbing the contact zone. Two O-rings were used on each 
rubber socket to seal the point of contact between the membrane and probes. (see Hight 1982 for more information on this procedure). Care was taken to ensure that the pwp probes were in contact with the surface specimen and kept at their initial locations. As seen in Fig. 5, a mesh was printed on the membrane before mounting. A series of 10-megapixel digital photographs were taken during the compression tests.

\section{Test program}

A series of plane strain tests were conducted, each of which involved consolidation followed by undrained compression (Table 3). Consolidation stress was applied in an $\mathrm{x}-\mathrm{Z}$ plane (Fig. 5) and chosen based on the expected level of in situ horizontal effective stress $(60-70 \mathrm{kPa})$. Previous experiments have shown that consolidation to higher effective stresses may destroy transported quick clay samples. A small backpressure of 10-15 kPa was applied. Tests were run under controlled displacement, and two rates of axial shortening were applied: 0.06 $\mathrm{mm} / \mathrm{min}$ and $0.006 \mathrm{~mm} / \mathrm{min}$ (note that the former is the rate typically used in undrained triaxial tests on quick clay). Globally undrained conditions were created by closing the drainage valves. Table 3 provides a short summary of the experimental program.

During the consolidation phase, two-way vertical drainage was allowed through the top and bottom of the sample. In this phase, plane strain conditions need to be maintained. It is possible that the thickness of the specimen (orthogonal to the sidewalls) can decrease, leading to the formation of a gap between the specimen and sidewalls. Therefore, consolidation stress had to be carefully selected and applied in order to maintain full contact between the sample and the sidewalls. Full contact appeared to be maintained for all tests reported herein. 


\section{Shear stress and deformation pattern of quick clays}

The shear stress $(t)$ and deformation patterns recorded during the tests are presented in Fig. 7. Here, $t$ is determined by $\left(\sigma_{z}^{\prime}-\sigma_{x}^{\prime}\right) / 2$, where $\sigma^{\prime}$ is the effective stress and $z$ and $x$ represent the vertical (axial) and horizontal directions of the plane of deformation. Peak shear stress $\left(t_{p}\right)$ varied from $20-30 \mathrm{kPa}$ in quick clay samples and was about $60 \mathrm{kPa}$ for the non-quick clay sample (T6). Failure axial strain $\left(\varepsilon_{p}\right)$ varied from 2-8\%. As expected, we observe strain softening after a peak, except for $\mathrm{T} 1$, which demonstrate low peak strength and thus is believed to be disturbed. For the other samples, peak shear stress was reduced by $30-50 \%$ when they were sheared at a nominal axial strain level (vertical deformation of the sample top divided by the initial sample height) of $10-15 \%$. Normalized peak shear stress $\left(\mathrm{t}_{\mathrm{p}} / \sigma_{\mathrm{zo}}\right)$ in the quick clay specimens was $0.25-0.35$. Here, $\sigma_{\mathrm{zo}}$ ' is the in situ effective vertical stress. T6 shows a surprisingly high value: 0.5 . The observed range of $t_{\mathrm{p}} / \sigma_{\mathrm{vo}}{ }^{\prime}$ is similar to that reported by Gylland et al. (2014) for quick clay.

The results show that quick clays tested under plane strain compression exhibited non-smooth stress-strain patterns. However, Fig. 1 suggests that quick clays exhibit a smooth stress-strain response when subjected to undrained triaxial loading. This difference in the stress-strain response in the triaxial and plane strain test results could be attributed to the imposed boundary conditions (stick slip between the glass plates) and/or the emergence and propagation of shear bands during the tests (see Scavia et al. 1997; Charrier et al. 2001; Viggiani et al. 2001; Marello et al. 2003; and Desrues and Viggiani 2004).

The emergence and propagation of shear bands during the undrained shearing phase were recorded by a continuous movie for tests $\mathrm{T} 1, \mathrm{~T} 3$, and $\mathrm{T} 4$ and by a series of 10-Megapixel 
images taken at different nominal axial strain levels during tests T2, T5, and T6. Image analyses were performed using the Davis V8.0 (2015) digital image correlation (DIC) tool.

DIC is a mathematical tool for assessing the spatial transformation (including translations and distortions) of two digital images. It allows regions of a photographed object to be tracked automatically from one digital image to the next, enabling the measurement of displacements. A strain field can be derived from the measured displacement field based on the gradients of the derived displacements and assumed continuum. A number of textbooks and papers describe this technique in detail, such as Hall (2012) and the many references therein.

DIC analyses were carried out for the T2, T5, and T6 tests, and the measured total and incremental shear strain distributions are presented in Figs. 7, 8, and 9, respectively. The incremental strain distributions were obtained from two consecutive images, while the total strain distributions were obtained by comparing an image with its initial image. It must be noted that the correlation between two images taken over long intervals may obscure certain important information; therefore, the selected intervals should be rather small to accurately capture deformation behavior. In a later part of this paper, the onset, formation, and propagation of bands during the tests were investigated with pwp non-uniformity, denoted $\Delta p_{w}$. Here, $\Delta p_{w}$ refers to the difference between the two probes' pwp readings.

\section{T2 test}

The $t$ and nominal axial strain $(\varepsilon)$ are presented in Fig. 7 along with the maximum deviatoric strain distribution resulting from the correlations for images taken from the start (P0) to the end (P8) of the test. The pwp non-uniformities (Fig. 7b) are discussed later. The total shear strain inside the sample was measured with DIC analysis of the images (P1 to P8) with 
respect to P0, as shown in Fig. 7c. The shear strain distribution in two consecutive images is shown in Fig. 7d.

The incremental shear strain distribution, which corresponds to the numbered points P0-P1 in the Fig. 7, shows slightly non-homogenous deformation in the test specimen, with incremental strains concentrated in the upper part of the specimen. This indicates that localization begins before the peak. The results for P1-P2 indicate the emergence of a shear band in the upper left corner of the specimen. The results for P3-P4 show a fully developed curved shear band emerging from the upper left to the middle right of the sample as well as a new shear band emerging from the upper right edge of the specimen and a distinct drop in shear stress between $\mathrm{P} 3$ and $\mathrm{P} 4$. The results for P4-P5 and P5-P6 show new shear bands progressing from the upper right edges of the specimen towards the lower left edges. However, at this stage, the progression of the shear bands in P3-P4 appears to be halted, which is peculiar because shear stress is gradually decreasing. Finally, the results for P7-P8 show that asymmetrical crossshaped shear bands are formed at the end of the test.

The DIC results indicate that the formation of shear bands in these tests on quick clay is progressive, asymmetric, and complex. The total and incremental shear strain distributions suggest that the shear bands propagate smoothly and gradually and that they are non-unique and keep fluctuating throughout the test (see Fig. 7). This observation indicates that certain parts of the shear bands must be subjected to more strain softening than others. The failure process continues until a kinematic mechanism is formed and divide the sample into several shear bands and non-localized zones. The shear strain inside the localized zones (e.g., $~ 30 \%$ for P0-P8) is three times the globally applied nominal strain $(\sim 10 \%$ at P8). Nominal axial strain of $10 \%$ corresponds to deformation of $12 \mathrm{~mm}$. Accordingly, the thickness of a shear 
band could be $36 \mathrm{~mm}$. The exact thickness of shear bands is difficult to measure in membrane-wrapped specimens. At the end of the test, the orientation of the shear bands varied from $45-50^{\circ}$ from the horizontal planes since they were curved.

\section{T5 test}

The results for P2-P3 show gradual growth of localized shear zones. The results for P3-P4 show a distinct shear band emerging from the upper left edge of the specimen prior to the peak. The P4-P5 and P5-P6 results vaguely indicate a completely developed shear band that is amplified in $\mathrm{P} 6-\mathrm{P} 7$ at a $53^{\circ}$ inclination from the horizontal planes. In the post-peak region, a new shear band emerges upward from the lower left of the specimen and proceeds toward the center (P6-P7). Finally, the results for P7-P8 reveal a nearly cross-shaped shear band inside the specimen, but the majority of localized strains are concentrated inside the original shear band observed at the peak, and the other shear band from the lower left to the upper right edge does not seem to grow. Similar to the T2 test, at the end of this test, the maximum shear strain inside the localized zones (e.g., $\sim 30 \%$ for $\mathrm{P} 0-\mathrm{P} 8)$ is three times the globally applied nominal strain ( $12 \%$ at P8). However, at the peak shear stress (P4-P5), the thickness of the shear band was only $4-5 \mathrm{~mm}$. The thickness of the shear bands increased in the localized zones towards the end. The DIC analysis shows that new shear bands emerge and fluctuate throughout the test.

\section{T6 test}

Fig. 9 shows rather diffuse deformation before the peak is reached in the T6 test, unlike the other two tests. It should be noted that the T6 test was carried out on less sensitive clay. The results for $\mathrm{P} 1-\mathrm{P} 2, \mathrm{P} 2-\mathrm{P} 3$, and $\mathrm{P} 0-\mathrm{P} 3$ reveal localized zones at the peak near the upper left and 
right edges of the test specimens. At the peak, the results for P3-P4 show a partially developed shear band emerging from the upper part of the specimen. Cross-shaped shear bands (P4-P5) develop simultaneously at a nominal axial strain of $8-9 \%$ and continue to grow until the end of the test. Finally, the P5-P6, P6-P7, and P7-P8 results show a fully developed, nearly symmetric cross-shaped shear band. The DIC results of the T6 test indicate that several thin shear bands form the ultimate kinematic failure mechanism. The shear bands tend to begin in the upper portion of the sample but move downwards and steepen towards the end of the test.

Test T6 results in an almost symmetric failure mode. The T2 and T5 tests show that the shear bands were initiated locally and gradually grew until the quick clay specimens were split into several localized zones. The thickness of the shear bands varied throughout the test. Thakur and Degago $(2012,2013)$ and Thakur et al. $(2013,2014)$ suggest that the collapsing behavior of sensitive clays with remolded shear strength of more than $1 \mathrm{kPa}$ is not as metastable as that of quick clays. In other words, sensitive clays with remolded shear strength of more than 1 $\mathrm{kPa}$ (such as $\mathrm{T} 6$ ) are more or less solid and therefore do not flow, whereas quick clays flow when they are remolded. This can explain why the results of the T6 test are similar to the failure patterns observed in less sensitive clays.

\section{Discussion of local pwp measurements}

The effective stress paths, which are determined by measuring pwp at the two probe locations, are presented in Fig. 10. Local pwp causes the two stress paths to differ in each test. In addition, minor differences in residual pwp at the end of the consolidation stage lead to different effective stresses at the probe locations. The local effective stress paths observed in the tests are plotted on $s^{\prime}-t$ plots. In this figure, $s^{\prime}$ represents the mean effective stresses 
$\left(\left[\sigma_{z}^{\prime}+\sigma_{x}^{\prime}\right] / 2\right), \sigma^{\prime}$ represents the effective stresses, and $z$ and $x$ represent the vertical (axial) and horizontal directions, respectively, in the plane of deformation shown in Fig. 5. The positive pwp generated during the tests confirms that quick clays exhibit contractive behavior during undrained shearing. The irregularity in the initial part of the effective stress paths in some tests could be partially due to stick slip friction against the glass walls.

In an $s^{\prime}-t$ plot, a stress path with a slope of 1:1 corresponds to drained plane strain compression. Parts of the stress paths in this study have such an inclination, which may suggest that there could be some air in the measurement system. Focus was actually on this issue during testing and the procedures used for saturation of the system were aiming at excluding air. However, the results suggest that in spite of all attempts to avoid air, the saturation of the measurement system was not $100 \%$.

Another consequence of the issue is that most of the effective stress paths do not end on the Mohr Coulomb failure line, simply because of local pwp variations. It was impossible to measure pwp in the shear band, and thus average pwp could not be obtained to correlate with the average total stresses, $\mathrm{s}$ and $\mathrm{t}$.

The measurements obtained from the two pwp probes were quite different. This difference was partially caused by variations in residual pwp at the end of the consolidation stage; residual pwp is highest at the center of the sample. To focus on differences in the development of pwp towards failure, the pwp data shown in Figs. 7, 8, and 9 are reset to zero at the start of the shearing stage, which corresponds to nominal axial strain $(\varepsilon)$ of $0 \%$, while Fig. 11 shows the actual measured values. 
There was much less excess pwp in the tests run at $0.006 \mathrm{~mm} / \mathrm{min}$ ( $\mathrm{T} 5$ and $\mathrm{T} 6$ ) compared to the tests run at $0.06 \mathrm{~mm} / \mathrm{min}(\mathrm{T} 1-\mathrm{T} 4)$. However, the opposite result was expected based on previous experience with quick clay; rapid tests normally show higher peak strength and lower pwp, while slow tests show less peak strength, earlier collapse, and higher pwp. At the beginning of the tests, T5 and T6 tended to build more excess pwp, but pwp decreased with increasing deformation. The current results indicate that there is some air in the system and that globally undrained conditions were not achieved. Phenomena such as dissipation into filter stones will become more pronounced over time. Thus, T5 and T6 show rather low pwp and the stress paths in Fig. 10 are "more drained" than the others. The results of all the tests run at $0.06 \mathrm{~mm} / \mathrm{min}$ indicate that pwp did not experience many peaks or sudden drops during shearing. However, the tests run at $0.006 \mathrm{~mm} / \mathrm{min}$ show more complex variations in pwp.

\section{Pore water pressure non-uniformities}

It can be difficult to directly measure pwp inside shear bands because it is impossible to predict the location of shear bands prior to the test. However, measurements near the shear bands may also provide significant information related to the onset of localization and local drainage situation. Variation in pwp measurements between the two probes should occur upon the emergence of a shear band close to one of the probes. Viggiani et al. (1994) observed this behavior in stiff clays, while Yaun et al. (2013) observed it for Shanghai silty clays.

The (b) plots in Figs. 7, 8, and 9 show the normalized pwp non-uniformities $\left(\left|\Delta p_{w}\right| / \sigma_{x o}{ }^{\prime}\right)$ in the $\mathrm{T} 2$, T5, and $\mathrm{T} 6$ tests, respectively. The term $\left|\Delta p_{w}\right| / \sigma_{x o}$ ' is used to determine the difference in the measurements recorded by two probes on one sample. The emergence of shear bands and variation in $\Delta p_{w}$ are interrelated, as shown in these figures. A decrease in $\left|\Delta p_{w}\right| / \sigma_{x o}$ ' was often observed when the shear bands were fully developed. However, $\left|\Delta p_{w}\right| / \sigma_{x o}$ ' increased when the 
shear bands propagated or grew progressively. The correlation between the DIC and $\left|\Delta p_{w}\right| / \sigma_{x o}$ ' results obtained during the $\mathrm{T} 2$ test shows that the emergence of the shear band and the first peak in the $\left|\Delta p_{w}\right| / \sigma_{x o}$ ' occurred at a nominal axial strain of $4 \%$. In addition, the DIC results for P1-P2 indicate the emergence of a shear band at the upper left corner of the specimen.

Similarly, the emergence of shear bands and peaks in $\left|\Delta p_{w}\right| / \sigma_{x o}$ ' were recorded at nominal axial strains of $2 \%$ and $6.4 \%$, respectively, during the T5 test. The distinct shear band that appeared at a nominal axial strain of $2 \%$ led to the growth of a distinct shear band from the upper left corner of the specimen as well as a sudden drop in $\left|\Delta p_{w}\right| / \sigma_{x o}$ ' and shear stress. A reduction in $\left|\Delta p_{w}\right| / \sigma_{x o}$, at a nominal axial strain greater than $6.4 \%$ could be related to a reduction in peak shear stress, in line with the DIC results. Peaks in $\left|\Delta p_{w}\right| / \sigma_{x o}$ ' were recorded at axial deformations of $1.5 \%, 5.5 \%, 7.5 \%$, and $11.5 \%$ during the T6 test and were associated with the initiation and propagation of shear bands inside the specimen. Interestingly, these peaks were difficult to observe in the plot of the T6 test shown in Fig. 9d.

The observed fluctuations in shear bands led to multiple peaks in $\left|\Delta p_{w}\right| / \sigma_{x o}$ ' throughout the test. The peaks in pwp non-uniformity observed during the T2 test and those observed by Yuan et al. (2013) in Shanghai silty clay are compared in Fig. 12. The trends are remarkably similar; in both studies, $\left|\Delta p_{w}\right| / \sigma_{x o}$ ' increased until the onset of localization (O) and there were insignificant variations in the $\left|\Delta p_{w}\right| / \sigma_{x o}$ ' until the formation of the primary shear band was completed (B). One could expect $\left|\Delta p_{w}\right| / \sigma_{x o}{ }^{\prime}=0$ for a homogenously deforming specimen. However, the data suggests that soft clay specimens may undergo non-uniform deformation prior to the onset of localization (e.g., $\left.\left|\Delta p_{w}\right| / \sigma_{x o}{ }^{\prime}>0\right)$. 
Variations in pwp between the two probes may also be caused by other effects. Even with careful calibration, measurement errors cannot be completely avoided. Further, variations in pwp during testing may be due to equalization of residual pwp after an unfinished consolidation phase, which leads to friction between the specimen and the glass wall or between the top/bottom plate and the specimen, or to non-homogeneities in the specimen itself. It should be noted that no sudden increases or decreases in $\left|\Delta p_{w}\right| / \sigma_{x o}$ ' were observed in any of the tests performed in this study, in contrast to the findings of Viggiani et al. (1994) regarding stiff clays. The present study reveals a complex interaction between generations of pwp in shear bands and during shear band formation. Non-smooth stress deformation patterns and irregular excess pwp are associated with the formation and propagation of shear bands in quick clays. However, it was difficult to determine the onset of shear bands in quick clays based on $\left|\Delta p_{w}\right| / \sigma_{x o}$ ' values alone, without the DIC results.

\section{Conclusions}

This study presents the behavior of quick clays under plane strain conditions. Localized deformations occur in fluctuating shear bands before a final failure mechanism is formed. A DIC analysis revealed that the process by which shear bands are formed in quick clays is quite complex. The formation of shear bands was progressive, asymmetric, and seemingly random, and the shear bands fluctuated throughout the tests. The accumulated strain inside the shear bands was as high as three to four times the applied nominal axial strains. The failure process continued until a kinematic mechanism is formed, dividing the sample into several shear bands and non-localized zones. The pwp measured at two different locations on the surface of the quick clay samples shows that shear banding leads to significant variations in the build-up of pwp within the sample, followed by local drainage of pore water. The local effective stress paths suggest that unloading was prevented in the neighboring soil material due to the influx 
of pore water to this soil from the shear bands. If the observation is correct, this implies that failure is less brittle than it might have been otherwise. The pwp measurements show that differences in locally measured pwp may indicate the onset of localization and gradual progression of shear bands inside the tested samples. The differences in locally measured pwp are rather modest in this study, which focused on quick clays, and are not as abrupt or large as previous studies that investigated stiff clays. This may be due to the low level of stress in the present study and some sample disturbance, which is hard to avoid when working with quick clays. A decrease in pwp non-uniformities was often observed when the shear bands were fully developed. However, these non-uniformities increased when the shear bands propagated or grew progressively. This study shows that the formation and propagation of shear bands are complex in quick clays.

\section{Acknowledgements}

Dr. H. P. Jostad from the Norwegian Geotechnical Institute is gratefully acknowledged for his kind support. The authors also thank Dr. J. Desrues from Laboratoire 3SR for useful discussions. The Geotechnical Group at NTNU, Norway is acknowledged for their help and technical assistance, and the International Centre for Geohazards NFR-CoE-ICG, Norway is acknowledged for providing financial support for this study. Dr. Samson Degago from the Norwegian Public Roads Administration is thanked for the manuscript editing and invaluable feedback. Finally, Ms. Helene Amundsen is acknowledged for providing the triaxial and odometer test results. 


\section{References}

Amundsen, H. A., Thakur, V., and Emdal, A. 2016. Sample disturbance in block samples of low plastic soft clays. In $6^{\text {th }}$ International Conference on Geotechnical and Geophysical Site Characterization, Queensland, Australia (in press).

Amundsen, H. A., Thakur, V., and Emdal, A. 2015. Comparison of two sample quality assessment methods applied to oedometer test results. Proceedings of the $6^{\text {th }}$ International Symposium on the Deformation Characteristics of Geomaterials, Vol. 6, pp. 923-930.

Amundsen, H. A., Jønland, J., Emdal, A., and Thakur, V. 2017. An attempt to monitor pwp changes in a block sample during and after sampling. Géotechnique Letters (under review).

Bernander, S. 2000. Downhill progressive failure in long natural slopes. Licentiate Thesis, Luleå University.

Bjerrum, L. 1955. Stability of natural slopes in quick clays. Geotechnique, 5(1): 101-119.

Boudali, M., 1995. Comportement tridimensionnel et visqueux des argiles naturelles. Ph.D. thesis, Laval University, Québec.

Charrier. P., Desrues, J., Lenti, L., and Viggiani, G. 2001. Experimental observation of strain localization in plane strain compression of Beaucaire marl. Internal report to IGS, Stuttgart, Germany.

Chehab, G., Seo, Y., and Kim, Y. 2007. Viscoelastoplastic damage characterization of asphalt-aggregate mixtures using digital image correlation. International Journal of Geomechanics, 7(1): 111-118.

Cheng, X. 2004. Localization in Dutch dune sand and organic clay. PhD thesis, TU Delft, The Netherlands.

Davis. 2015. Davis LaVision, Version 8. www.lavision.de

Desrues, J., and Duthilleul, B. 1984. Mesure du champ de déformation d'un objet plan par la méthode stéréophotogrammétrique de faux relief. Journal de Mécanique Théorique et Appliquée, 3(1): 79-103.

Desrues, J. 1984. La localisation de la deformation dans les mat !eriaux granulaires. These de 22eo mechanic science. USMG and INPG: Grenoble, France.

Desrues, J. 1990. Shear band initiation in granular materials: experimentation and theory. Geomaterials: Constitutive Equations and Modelling, pp. 283-310. Elsevier: Amsterdam.

Desrues, J., and Viggiani, G. 2004. Strain localization in sand: an overview of the experimental results obtained in Grenoble using stereophotogrammetry. International Journal of Numerical and Analytical Methods in Geomechanics, 28(4): 279-321. 
Emdal, A., Gylland, Amundsen, H.A., Kåsin, K., and Long, M. 2016. Mini-block sampler. Canadian Geotechnical Journal 53:1235-1245.

Finno, R. J., and Rhee, Y. 1992. Kinematically unconstrained compression of soft clay. Proceedings of Specialty Conference on Stability and Performance of Slopes and Embankments, ASCE, Berkeley, Vol. 2, pp. 142-157.

Gregersen, O. 1981. The quick clay landslide in Rissa, Norway. Proceedings of the $10^{\text {th }}$ International Conference on Oil Mechanics and Foundation Engineering, Stockholm, Vol. 3, pp. 421-426.

Grimstad, G., and Jostad, H. P. 2012. Stability analyses of quick clay using FEM and an anisotropic strain softening model with internal length scale. Nordic Geotechnical Meeting, Copenhagen, pp. 675-680.

Grimstad, G., Thakur, V., and Nordal, S. 2005. Experimental investigation of formation and propagation of shear zone in Norwegian quick clay. $11^{\text {th }}$ International Conference on Field Trips to Landslides, Trondheim, Norway, pp. 137-141.

Gylland, A., Jostad, H. P., and Nordal, S. 2013. Experimental study of strain localization in sensitive clays. Acta Geotechnica, 9(2): 227-240.

Gylland, A. S., Long, M., Emdal, A., and Sandven, R. 2013. Characterisation and engineering properties of Tiller clay. Engineering Geology 164: 86-100.

Gylland, A., Sayd, M., Jostad, H. P., and Bernander, S. 2010. Investigation of soil property sensitivity in progressive failure. Proceedings of the $7^{\text {th }}$ European Conference on Numerical Methods in Geotechnical Engineering, T. Benz and S. Nordal (Eds.), Trondheim, Norway, pp. 515-520.

Hight, D. W. 1982. A simple piezometer probe for routine measurement of pwp in triaxial tests on saturated soils. Géotechnique, 32(4): 396-401.

Hall, S. A. 2012. Digital image correlation in experimental geomechanics. Advanced Experimental Techniques in Geomechanics, G. Viggiani, S. A. Hall, and E. Romero (Eds.), pp. 69-102.

Hammad, W. 1991. Modélisation non linéaire et étude expérimentale des bandes de cisaillement dans les sables. Ph.D. Thesis, University Josef Fourier, Grenoble, France.

Han, C., and Vardoulakis, I. 1991. Plane strain compression experiments on watersaturated fine-grained sand. Geotechnique, 41(1): 49-78.

Han, C. 1991. Localization of deformation in sand. Ph.D. Dissertation, University of Minnesota, Minneapolis.

Han, C., and Vardoulakis, I. G. 1991. Plane strain compression experiments on watersaturated fine-grained sand, Géotechnique, 41(1): 49-78.

Harris, W.W., Viggiani, G., Mooney, M.A., and Finno, R.J. 1995. Use of stereophotogrammetry to analyze the development of shear bands in sand. Geotechnical Testing Journal, ASTM, 18(4): 405-420. 
Janbu, N. 1979. Failure mechanism in quick clay. Nordic Geotechnical Meeting, Helsingfors.

Jostad, H. P., and Andresen, L. 2002. Bearing capacity analysis of anisotropic and strainsoftening clay. Numerical Models in Geomechanics: Proceedings of the $8^{\text {th }}$ International Symposium, NUMOG VIII, Rome, Italy, pp. 469-474.

Jostad, H. P., Andresen, L., and Thakur, V. 2006. Calculation of shear band thicknesses in sensitive clays. Proceedings of the $6^{\text {th }}$ European Conference for Numerical Methods in Geotechnical Engineering, Austria, pp. 27-32.

Jostad, H. P., Fornes, P., and Thakur, V. 2014. Effect of strain-softening in design of fills in gently inclined areas with soft sensitive clays. First International Workshop on Landslide in Sensitive Clays. Advances in Natural and Technological Hazards Research 36(24): 305-316.

Karlsrud, K., and Hernandez-Martinez, F. G. 2013. Strength and deformation properties of Norwegian clays from laboratory tests on high quality block samples. Canadian Geotechnical Journal, 50(12): 1273-1293.

Karlsrud, K., Aas, G., and Gregersen, O. 1985. Can we predict landslide hazards in soft sensitive clays? Summary of Norwegian practice and experience. NGI Publication 158.

Lenoir, N., Bornert, M., Desrues, J., Bésuelle, P., and Viggiani, G. 2007. Volumetric digital image correlation applied to $\mathrm{X}$-ray microtomography images from triaxial compression tests on argillaceous rocks. International Journal for Experimental Mechanics, 43(3): 193-205.

Lizcano, A., Vardoulakis, I., and Goldscheider, M. 1997. Biaxial tests on normally anisotropically consolidated kaolin clay. Inelastic Deformation and Progressive Failure in 24eomechanics, Pergamon, UK, pp. 223-227.

Lu, X. B., Wang, S. Y., and Peng, C. 2004. On the evaluation of simple shear in saturated soils. International Journal of Numerical and Analytical Methods in Geomechanics, 28(3), 269-278.

Marello, S. 2005. Experimental study of shear bands in fine grained soils. $11^{\text {th }}$ International Conference on Computer Methods and Advances in Geomechanics, IACMAG, Torino, Italy, Vol. 2, pp. 119-126.

Marello, S., Lenoir, N., Viggiani, G., Bésuelle, P., Desrues, J., and Di Michiel, M. 2003. Shear banding in plane strain compression of Beaucaire Marl studied through postmortem X-ray micro tomography. Proceedings of the International Workshop on Xray CT for Geomaterials, Soils, Concrete, Rocks, GeoX, Kumamoto, Japan, J. Otani and Y. Obara (Eds.), Balkema, pp. 39-146.

Mitchell, R.J., and Wong, K.K. 1973. The Generalized Failure of an Ottawa Valley Champlain Sea Clay. Canadian Geotechnical Journal 10: 607-616. 
Mokni, M., and Desrues, J. 1999. Strain 25eo mechanics measurements in undrained plane strain biaxial tests on Hostun RF sand. Mechanics of Cohesive-Frictional Materials, 4(4): 419-441.

Mooney, M.A., Finno, R.J., and Viggiani, G. 1998. A unique critical state for sand? Journal of Geotechnical and Geoenvironmental Engineering, ASCE, 124(11): 11001108 .

NGF. 1974. Guidelines by the Norwegian Geotechnical Forum on presentation of the geotechnical investigation. Norwegian Geotechnical Forum, Oslo, Norway.

Nordal, S., Alen, C., Emdal, A., Jendeby, L., Lyche, E., and Madshus, C. 2009. Skredet i Kattmarkvegen i Namsos, 13 March 2009. A report to the transportation Ministry of Norway.

Rhee, Y. 1991. Experimental evaluation of strain-softening behavior of natural and reconstituted samples of two over consolidated clays. Proceedings of the International Symposium on Hard Soils and Soft Rocks, Athens, Greece, Vol. 1, pp. 769-778.

Roger, V., Desrues, J., and Viggiani, G. 1998. Experiments on strain 25eomechanics in dense sand under isochoric conditions. Localization and Bifurcation Theory for Soils and Rocks, T. Adachi, F. Oka, and A. Yashima (Eds). Balkema: Rotterdam, pp. 239248.

Rosenqvist, I. 1953. Consideration on the sensitivity of Norwegian quick clay. Geotechnique, 5(1): 95-200.

Saada, A.S., Bianchini, G.F., and Liang, L. 1994. Cracks, bifurcation and shear bands propagation in saturated clays. Geotechnique, 44(1): 35-64.

Sandven, R. 1990. Strength and deformation properties of fine grained soils obtained from piexocone tests. Ph.D. Thesis, NTNU, Norway

Scavia, C., Viggiani, G., Castelli, M., and Desrues, J. 1997. An experimental and numerical study of shear fracture propagation in rock. Deformation and Progressive Failure in Geomechanics, Proceedings of IS-Nagoya '97, A. Asaoka, T. Adachi and F. Oka (Eds.), Pergamon, pp. 175-180.

Shuttle, D.A., and Smith, I.M. 1990. Localization in the presence of excess pwp. Computers and Geotechnics, 9(1), 87-89.

Skempton, A.W., and Northey, R.D. 1952. Sensitivity of clays. Geotechnique, 3(1): 4051.

Teunissen, J. 2008. Shear band analysis in the biaxial test. International Journal of Geomechanics, 8(5): 311-321.

Thakur, V. 2011. Numerically observed shear bands in quick clays. International Journal of Geomechanics and Geoengineering, 6(2): 131-146. 
Thakur, V., and Degago, S.A. 2014. Quickness test approach for assessment of flow slide potentials. International Geotechnical Engineering Journal of the SEAGS \& AGSSEA, 45(1): 85-94.

Thakur, V., and Degago, S.A. 2012. Quickness of sensitive clays. Géotechnique Letters, 2(3): 87-95.

Thakur, V., and Degago, S.A. 2013. Disintegration energy of sensitive clays. Géotechnique Letters, 3(1): 21-25.

Thakur, V., Degago, S.A., Oset, F., Aabøe, R., Dolva, B.K., Aunaas, K., Nyheim, T., Lyche, E., Jensen, O.A., Saeter, M.B., et al. 2014. Characterization of post-failure movements of landslides in soft sensitive clays. Natural Hazards: Advances in Natural and Technological Hazards Research, 36: 91-103.

Thakur, V., Grimstad, G., and Nordal, S. 2006. Instability in quick clays. Proceedings of the Engineering Conference International Series: Geohazards, Lillehammer, Norway, P7., http://services.bepress.com/eci/geohazards/43Thakur 2006.

Thakur, V., Nordal, S., Jostad, H. P., and Andresen, L. 2005. Study on pwp dissipation during shear banding in sensitive clays. $11^{\text {th }}$ International Conference on Computer Methods and Advances in Geomechanics, IACMAG, Turino, Italy, Vol. 4, pp. 289296.

Thakur, V., Nordal, S., Stijacic, A., Jostad, H.P., and Andresen, L. 2008. Numerical modelling of orientation of partly drained shear band. Proceedings of $12^{\text {th }}$ International Conference of International Association for Computer Methods and Advances in 26eomechanics, GOA, pp. 1132-1139

Thakur, V., Degago, S.A., Oset, F., Dolva, B.K., and Aabøe, R. 2013. Une nouvelle approche pour évaluer le potentiel de Coulée dans les argiles sensibles (A new approach to assess the potential for flow slide in sensitive clays). International Conference on Soil Mechanics and Geotechnical Engineering, ISSMGE, Paris, France, pp. 2265-2269.

Topolnicki, M., Gudehus, G., and Mazurkiewicz, B.K. 1990. Observed stress-strain behavior of remoulded saturated clay under plane strain conditions. Geotechnique, 40(2): $155-187$.

Vardoulakis, I., Goldscheider, M. 1981. Biaxial apparatus for testing shear bands in soils. Proceedings of the $10^{\text {th }}$ ICSMFE, Stockholm. Balkema: Rotterdam, 4/61, pp. 819-824.

Vardoulakis, I. 1988. Theoretical and experimental bounds for shear-band bifurcation strain in biaxial tests on dry sand. Research Mechanica, 23: 239-259.

Vardoulakis, I.G., and Goldscheider, M. 1981. Biaxial apparatus for testing shear bands in soils, Proceedings of the $10^{\text {th }}$ International Conference on Oil Mechanics and Foundation Engineering, Stockholm, Vol. 4, pp. 819-824.

Viggiani, G., Finno, R.J., and Harris, W.W. 1994. Experimental observations of strain localization in plane strain compression of a stiff clay. Localization and Bifurcation 
Theory for Soils and Rocks, R. Chambon, J. Desrues, and I. Vardoulakis (Eds.), Balkema, pp. 189-198.

Viggiani, G., Küntz, M., and Desrues J. 2001. An experimental investigation of the relationship between grain size distribution and shear banding in granular materials. Continuous and Discontinuous Modeling of Cohesive Frictional Materials, P. A. Vermeer et al. (Eds.), Springer, pp. 111-127.

Yoshida, T., Tatsuoka, F., Kamegai, Y., Siddiquee, M.S.A., and Park, C.S. 1994. Shear banding in sands observed in plane strain compression. Localisation and Bifurcation Theory for Soils and Rocks, R. Chambon, J. Desrues, and I. Vardoulakis (Eds.), Balkema: Rotterdam, pp. 165-179.

Yuan, J., Zhang, Q., Li, B., and Zhao, X. 2013. Experimental analysis of shear band formation in plane strain tests on Shanghai silty clay. Bulletin of Engineering Geology and the Environment, 72: 107-114.

Zhou, H., and Randolph, M.F. 2007. Computational techniques and shear band development for cylindrical and spherical penetrometers in strain-softening clay. International Journal of Geomechanics, 7(4): 287-295. 


\section{Figure captions}

Figure 1. Illustration of the effect of sample disturbance on the results of a consolidated undrained triaxial compression (CUC) test and a constant rate of strain (CRS) oedometer on Tiller quick clays sampled using a 54-mm-diameter cylinder and a 160-mm-diameter mini Sherbrook block sampler developed by Emdal et al. (2016). The CUC tests were done at a strain rate of $1.2 \% / \mathrm{hr}$, and the CRS tests were done at $6.0 \% / \mathrm{hr}$. The properties of the tested materials are shown in Table 2. Here, $\mathrm{M}$ is the odometer modulus, $\varepsilon_{\mathrm{v}}$ is the volumetric strain, p' is the mean effective stress, and q is the deviatoric stress.

Figure 2. Excess pwp may develop and then dissipate during the formation and propagation of shear bands in slopes and laboratory samples of quick clay. The shear stress and shear strain patterns for two soil elements, A and B, are shown. Element A is located inside the shear band, and element B is located outside the shear band. Element A has already been subjected to strain softening, whereas element B has yet not reached its peak shear stress.

Figure 3. The plane strain apparatus.

Figure 4. Method for preparing specimen for the tests: (1) mold in its split form, with outer and inner shells; (2) assembled mold; (3) membrane placed on the outer shell and lateral supports mounted to support the top plate; (4) inner shell holding the specimen inside the outer shell; (5) shells that can be removed together, leaving the specimen inside the membrane.

Figure 5. Left: quick clay specimen with pore water pressure (pwp) transducers and lateral supports. Middle: quick clay specimen mounted in the plane strain apparatus. Right: specimen size and axis directions adopted in this study.

Figure 6. Shear stress $(t)$ and nominal axial strain $(\varepsilon)$ plots for the tested specimen.

Figure 7. DIC results for the T2 test. (a): Shear stress versus relative deformation (nominal or globally measured strain). The positions P0 to P8 show where images are taken. (b): 
Normalized pore water pressure difference $(\mathrm{CP}-\mathrm{BP})$ versus relative deformation, (reset to zero difference at the end of consolidation). (c): The total shear strain distribution on the sample surface computed using the DIC technique. (d): The incremental shear strain distribution on the sample surface computed using the DIC technique. [Note: Colored images can be found in the electronic version of this paper.]

Figure 8. DIC results for the T5 test. (a): Shear stress versus relative deformation (nominal or globally measured strain). The positions P0 to P8 show where images are taken. (b): Normalized pore water pressure difference $(\mathrm{CP}-\mathrm{BP})$ versus relative deformation, (reset to zero difference at the end of consolidation). (c): The total shear strain distribution on the sample surface computed using the DIC technique. (d): The incremental shear strain distribution on the sample surface computed using the DIC technique. [Note: Colored images can be found in the electronic version of this paper.]

Figure 9. DIC results for the T6 test. (a): Shear stress versus relative deformation (nominal or globally measured strain). The positions P0 to P8 show where images are taken. (b): Normalized pore water pressure difference $(\mathrm{TP}-\mathrm{CP}$ ) versus relative deformation, (reset to zero difference at the end of consolidation). (c): The total shear strain distribution on the sample surface computed using the DIC technique. (d): The incremental shear strain distribution on the sample surface computed using the DIC technique. [Note: the colored images can be found in the electronic version of this paper.]

Figure 10. Effective stress paths obtained for the plane strain tests. In this figure, s' represents the mean effective stress $\left(\left(\sigma_{\mathrm{z}}{ }^{\prime}+\sigma_{\mathrm{x}}{ }^{\prime}\right) / 2\right)$, $\mathrm{t}$ denotes the shear stress $\left(\sigma_{\mathrm{z}}{ }^{\prime}-\sigma_{\mathrm{x}}{ }^{\prime}\right) / 2$, and $\sigma^{\prime}$ are the effective stresses; the subscripts $\mathrm{z}$ and $\mathrm{x}$ stand for the axial and horizontal direction in the plane of deformation. The dotted line refers to a failure line corresponding to $\mathrm{c}=6 \mathrm{kPa}$ and $\varphi$ $=26.5^{\circ}$. The selected $\mathrm{c}$ and $\varphi$ values are typical for quick clays for this site.

Figure 11. Measured pore water pressure at the probe locations vs relative deformation $(\varepsilon)$ for the plane strain tests. The locations of the probes on the samples are shown. LP, RP, CP, BP, and TP refers to left probe, right probe, central probe, bottom probe and top probe respectively. Here, $\mathrm{H}$ is the sample height which is equal to $120 \mathrm{~mm}$. 
Figure 12. Comparison of pore water pressure non-uniformities observed in quick clay in this study and those observed by Yuan et al. (2013) in Shanghai silty clay. 


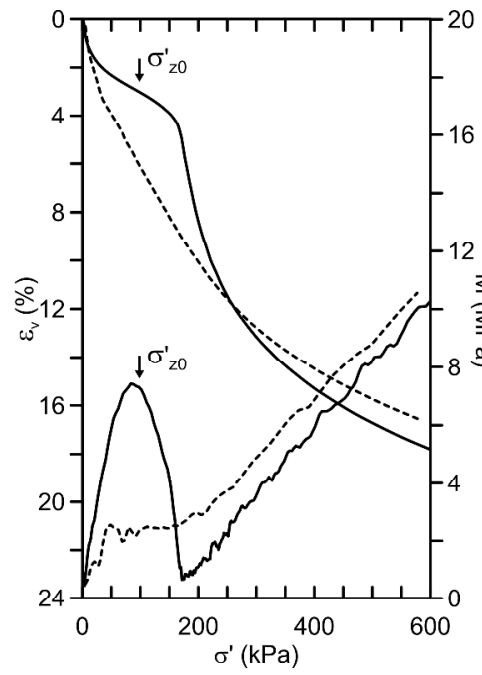

(a)

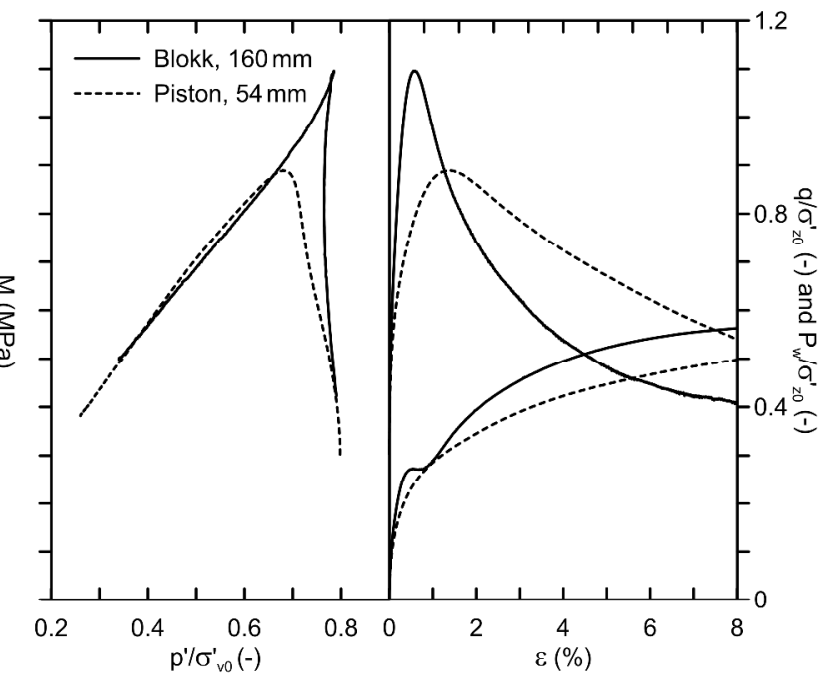

(b)

(c)

Figure 1. Illustration of the effect of sample disturbance on the results of a consolidated undrained triaxial compression (CUC) test and a constant rate of strain (CRS) oedometer on Tiller quick clays sampled using a 54-mm-diameter cylinder and a 160-mm-diameter mini Sherbrook block sampler developed by Emdal et al. (2016). The CUC tests were done at a strain rate of $1.2 \% / \mathrm{hr}$, and the CRS tests were done at $6.0 \% / \mathrm{hr}$. The properties of the tested materials are shown in Table 2 . Here, $\mathrm{M}$ is the odometer modulus, $\varepsilon \mathrm{V}$ is the volumetric strain, $\mathrm{p}^{\prime}$ is the mean effective stress, and $\mathrm{q}$ is the deviatoric stress. 


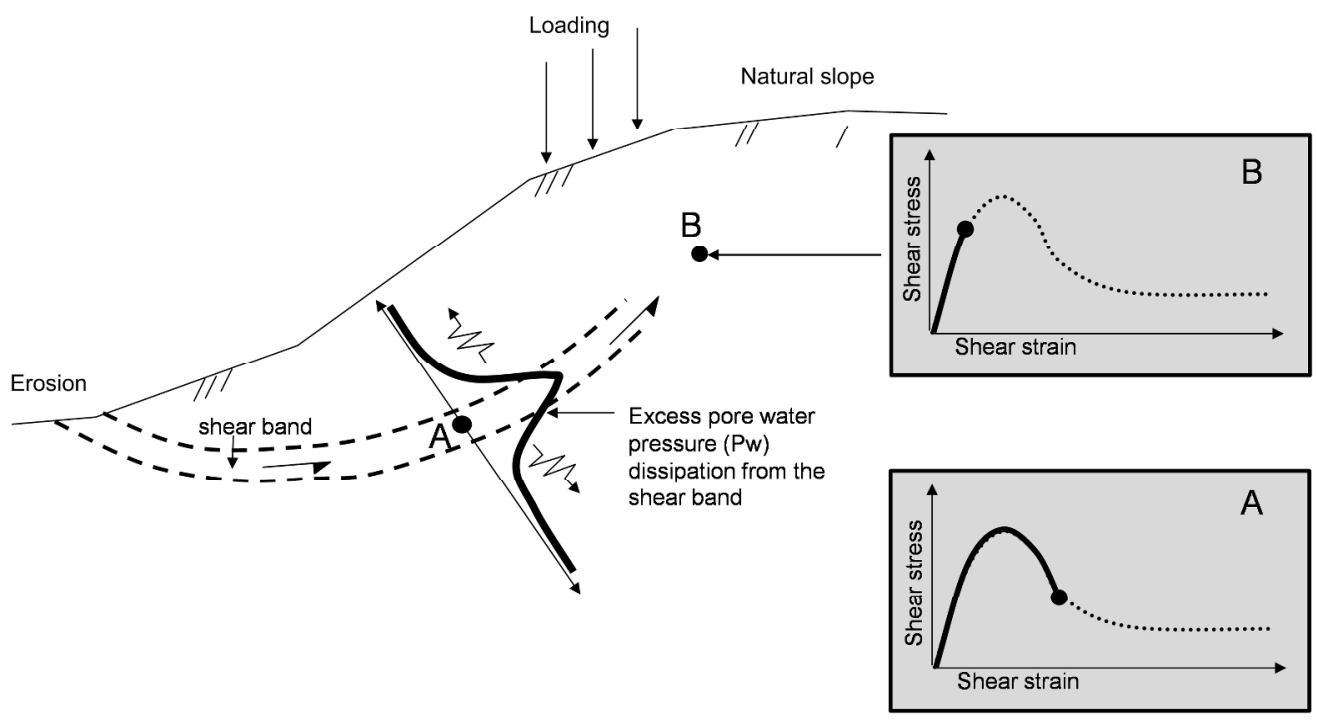

Figure 2. Excess pwp may develop and then dissipate during the formation and propagation of shear bands in slopes and laboratory samples of quick clay. The shear stress and shear strain patterns for two soil elements, A and B, are shown. Element A is located inside the shear band, and element $B$ is located outside the shear band. Element A has already been subjected to strain softening, whereas element $B$ has yet not reached its peak shear stress. 


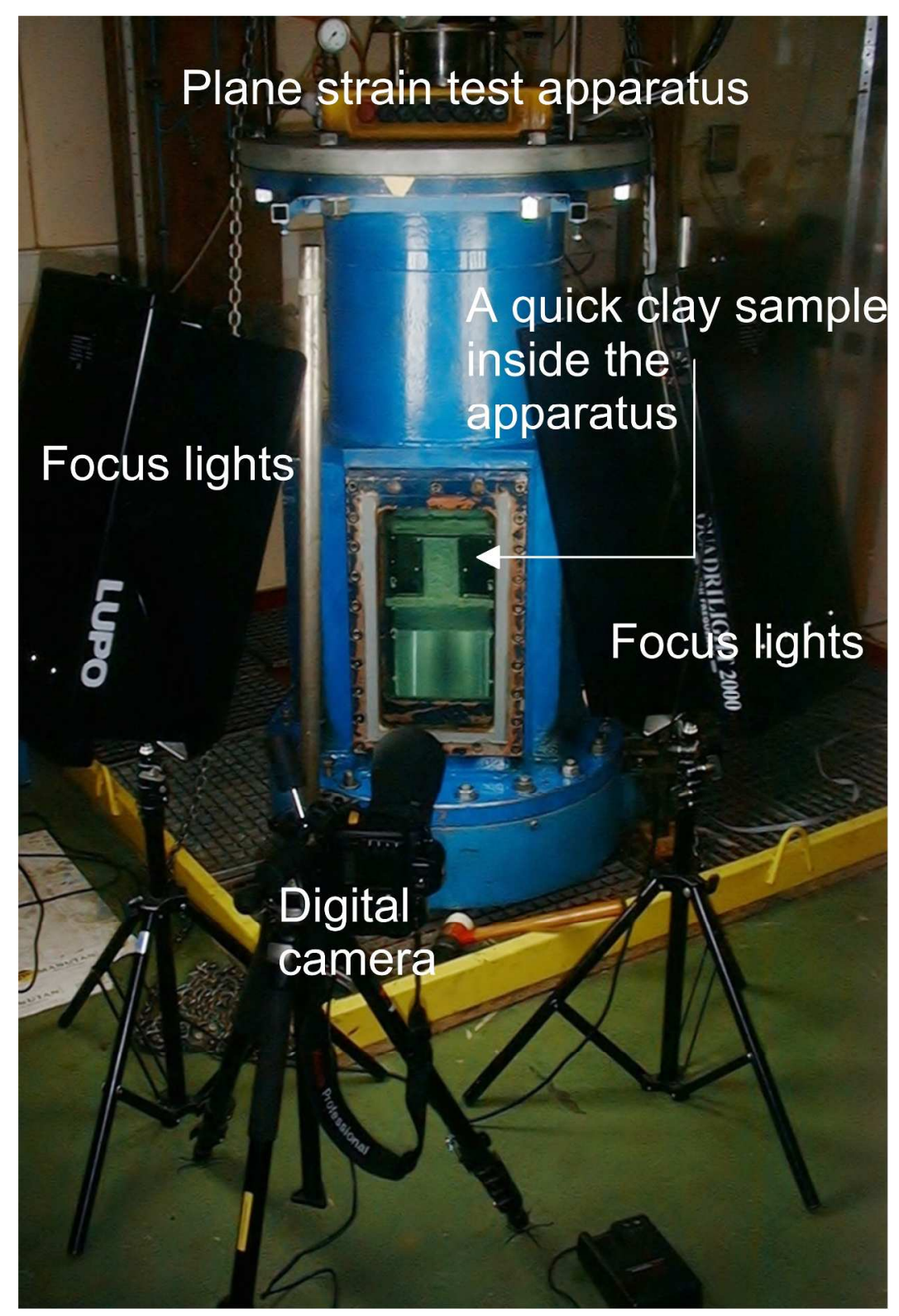

Figure 3: The plane strain apparatus 


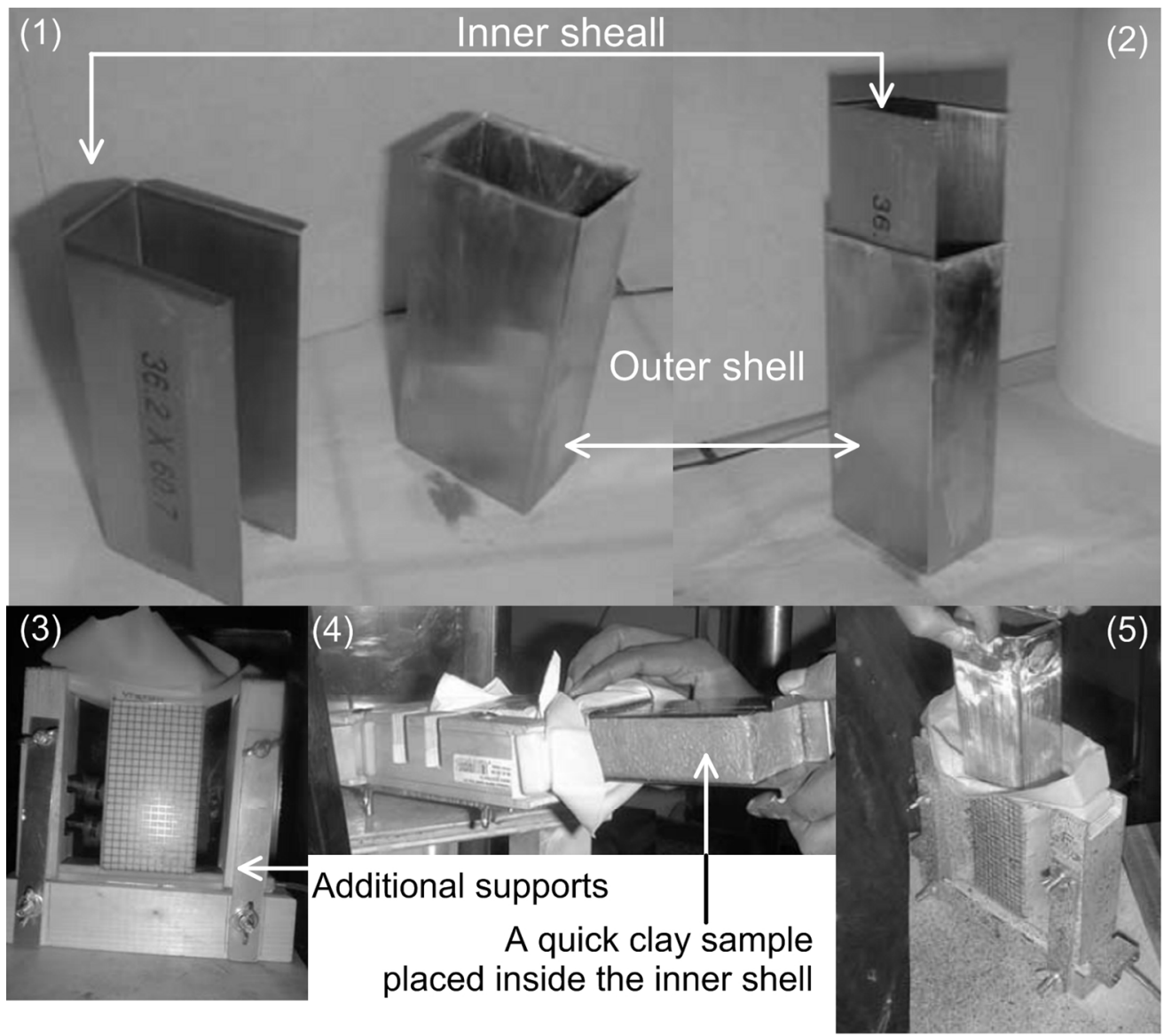

Figure 4. Method for preparing specimen for the tests: (1) mold in its split form, with outer and inner shells;

(2) assembled mold; (3) membrane placed on the outer shell and lateral supports mounted to support the top plate; (4) inner shell holding the specimen inside the outer shell; (5) shells that can be removed together, leaving the specimen inside the membrane. 

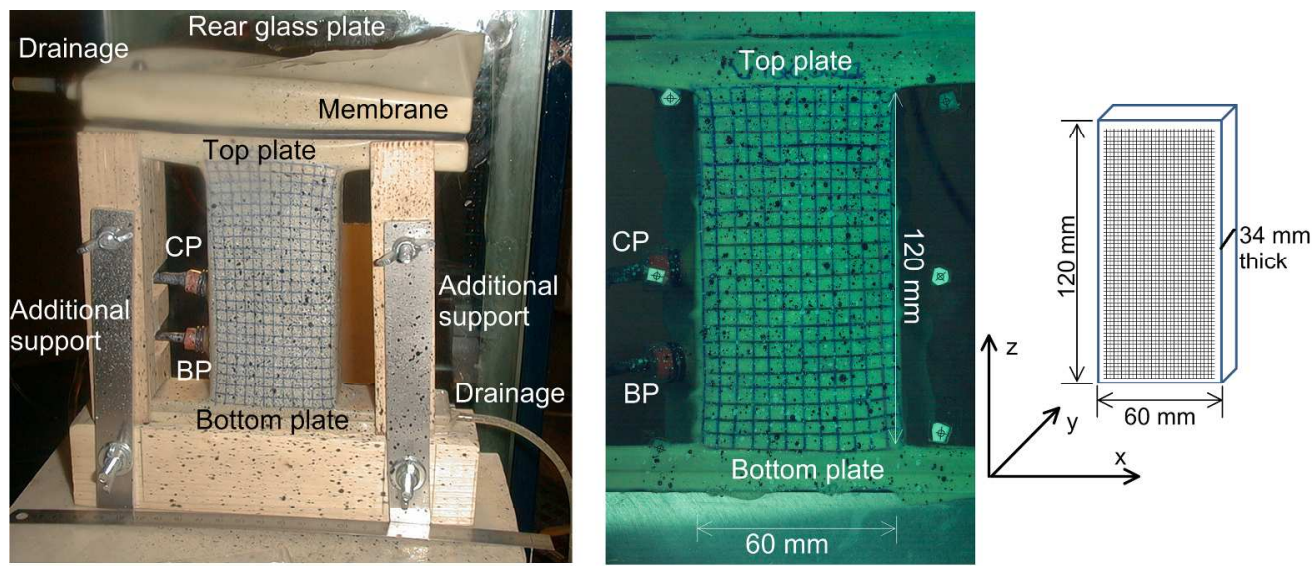

Specimen with pore pressure probes and A quick clay specimen, finally, the lateral supports mounted on the plane-strain aparatus

Figure 5. Left: quick clay specimen with pore water pressure (pwp) transducers and lateral supports. Middle: quick clay specimen mounted in the plane strain apparatus. Right: specimen size and axis directions adopted in this study. 

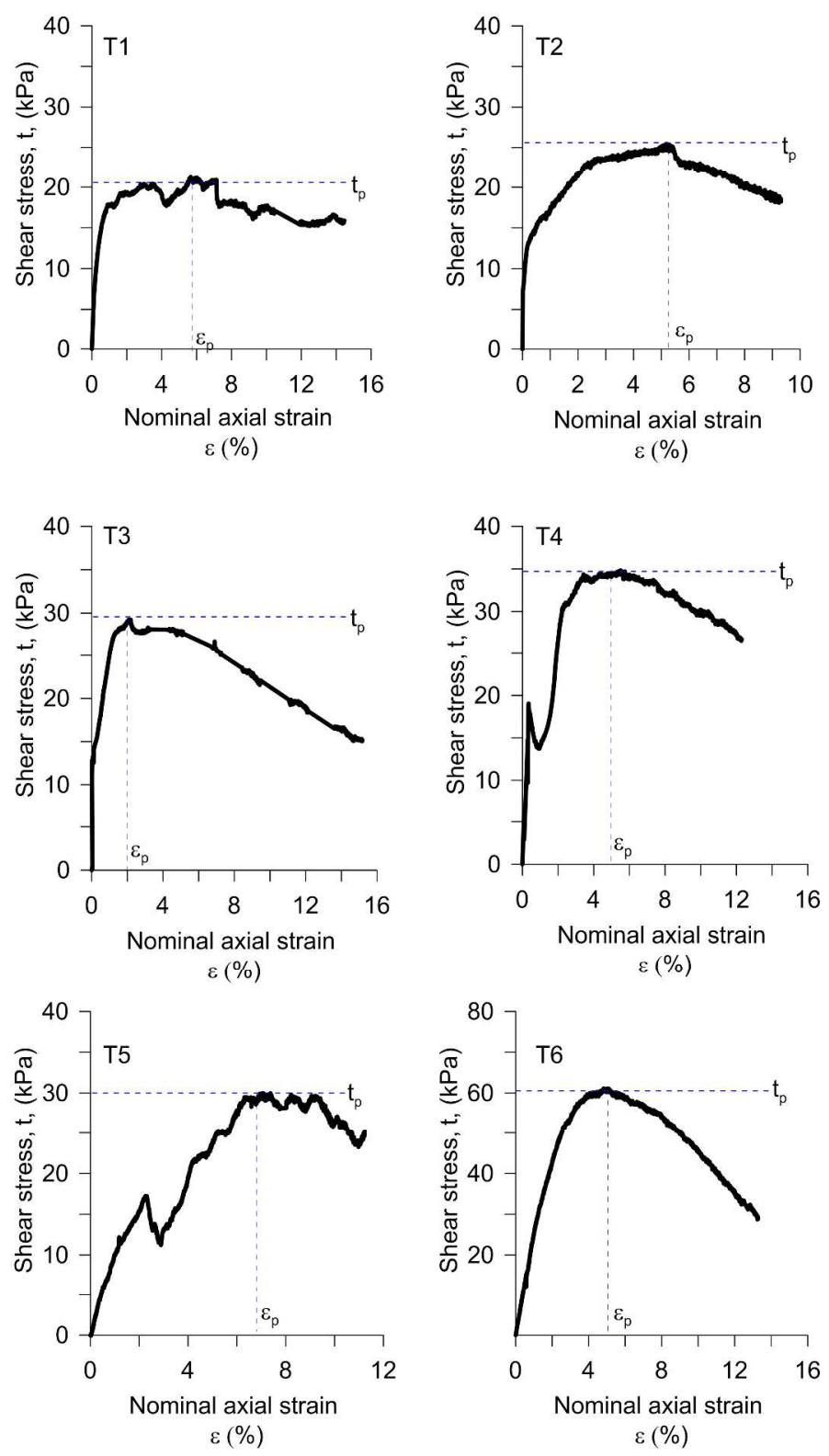

Figure 6. Shear stress $(t)$ and nominal axial strain $(\varepsilon)$ plots for the tested specimen 
T2 test
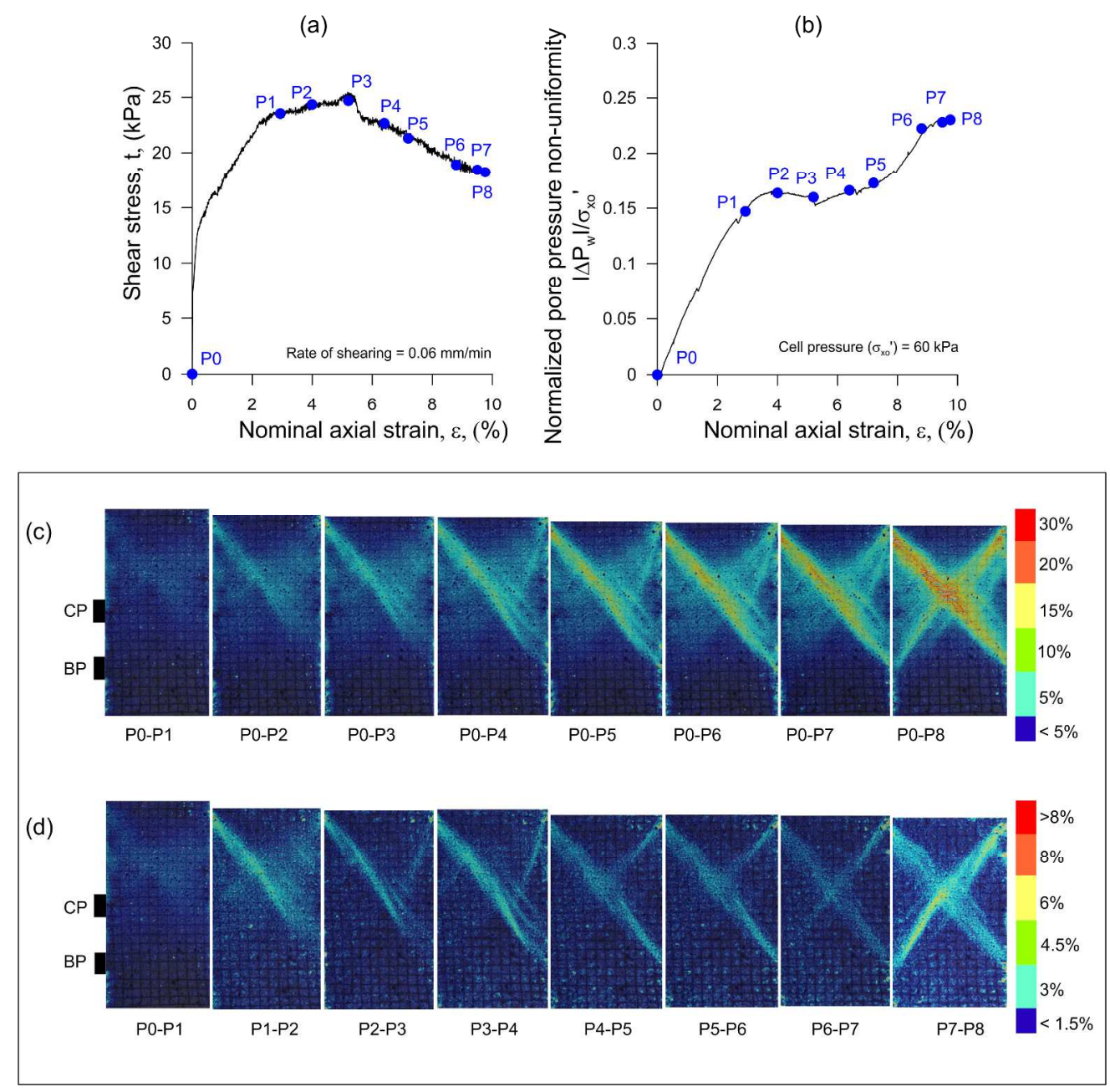

Figure 7. DIC results for the T2 test. (a): Shear stress versus relative deformation (nominal or globally measured strain). The positions P0 to P8 show where images are taken. (b): Normalized pore water pressure difference (CP - BP) versus relative deformation, (reset to zero difference at the end of consolidation). (c): The total shear strain distribution on the sample surface computed using the DIC technique. (d): The incremental shear strain distribution on the sample surface computed using the DIC technique. [Note: the colored images can be found in the electronic version of this paper.] 
T5 test
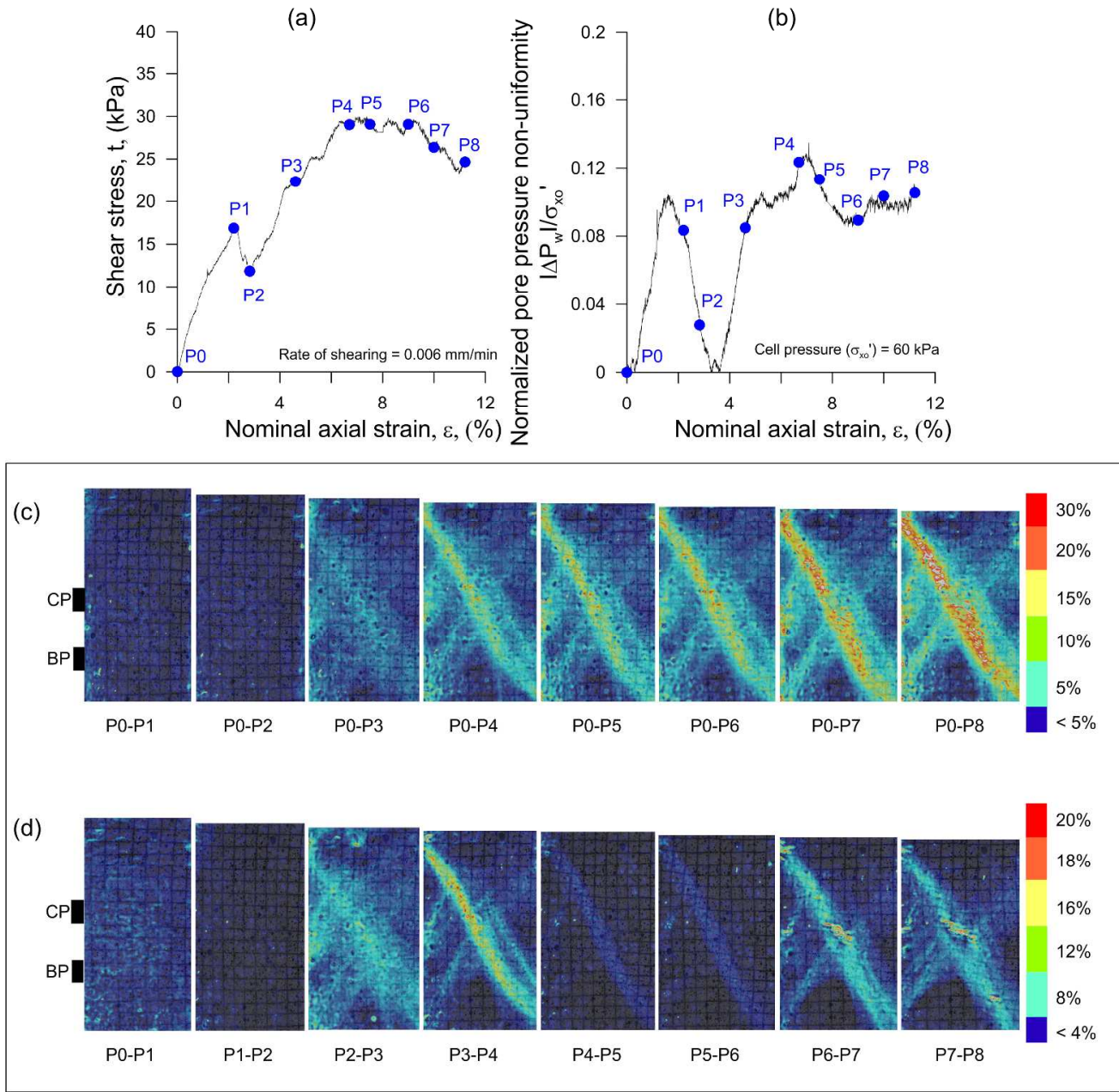

Figure 8. DIC results for the T5 test. (a): Shear stress versus relative deformation (nominal or globally measured strain). The positions P0 to P8 show where images are taken. (b): Normalized pore water pressure difference (CP - BP) versus relative deformation, (reset to zero difference at the end of consolidation). (c): The total shear strain distribution on the sample surface computed using the DIC technique. (d): The incremental shear strain distribution on the sample surface computed using the DIC technique. [Note: the colored images can be found in the electronic version of this paper.] 
T6 test

(a)

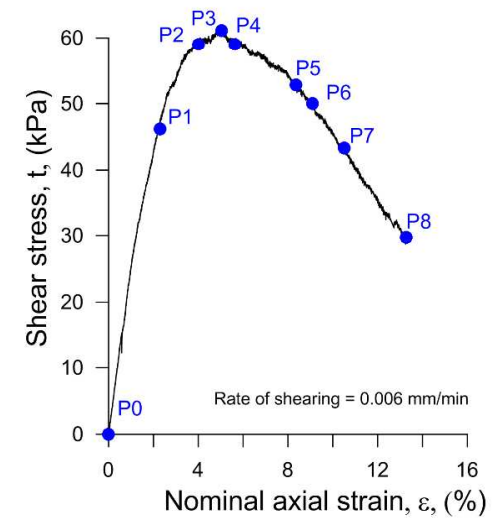

(b)

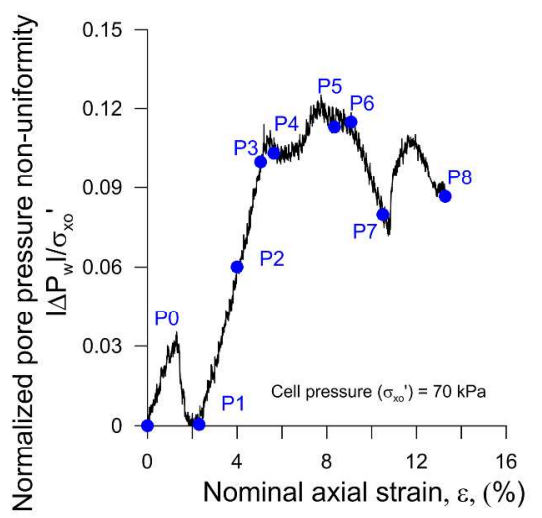

(c)

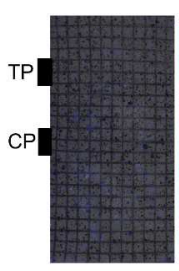

P0-P1

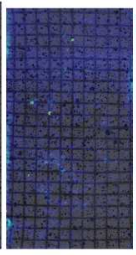

P0-P2

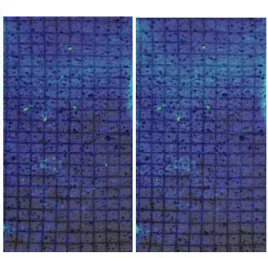

P0-P3

P0-P4

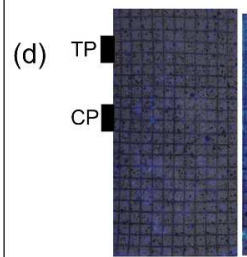

P0-P1

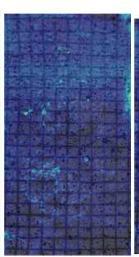

P1-P2

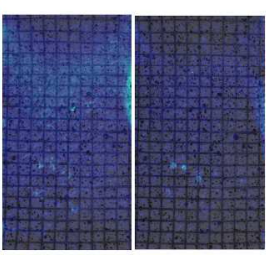

P2-P3

P3-P4

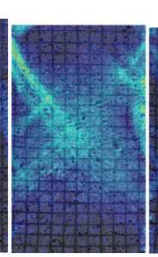

P4-P5

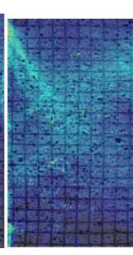

P0-P5

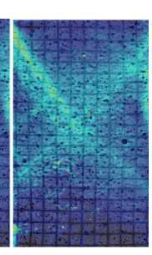

P0-P6

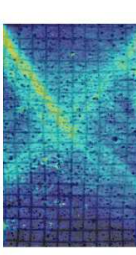

P0-P7

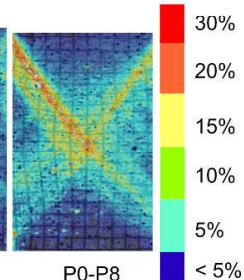

P0-P8

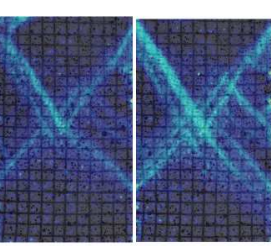

P5-P6

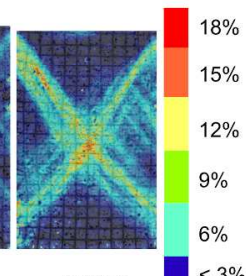

P6-P7

P7-P8

$<3 \%$

Figure 9. DIC results for the T6 test. (a): Shear stress versus relative deformation (nominal or globally measured strain). The positions P0 to P8 show where images are taken. (b): Normalized pore water pressure difference (TP - CP) versus relative deformation, (reset to zero difference at the end of consolidation). (c): The total shear strain distribution on the sample surface computed using the DIC technique. (d): The incremental shear strain distribution on the sample surface computed using the DIC technique. [Note: the colored images can be found in the electronic version of this paper.] 

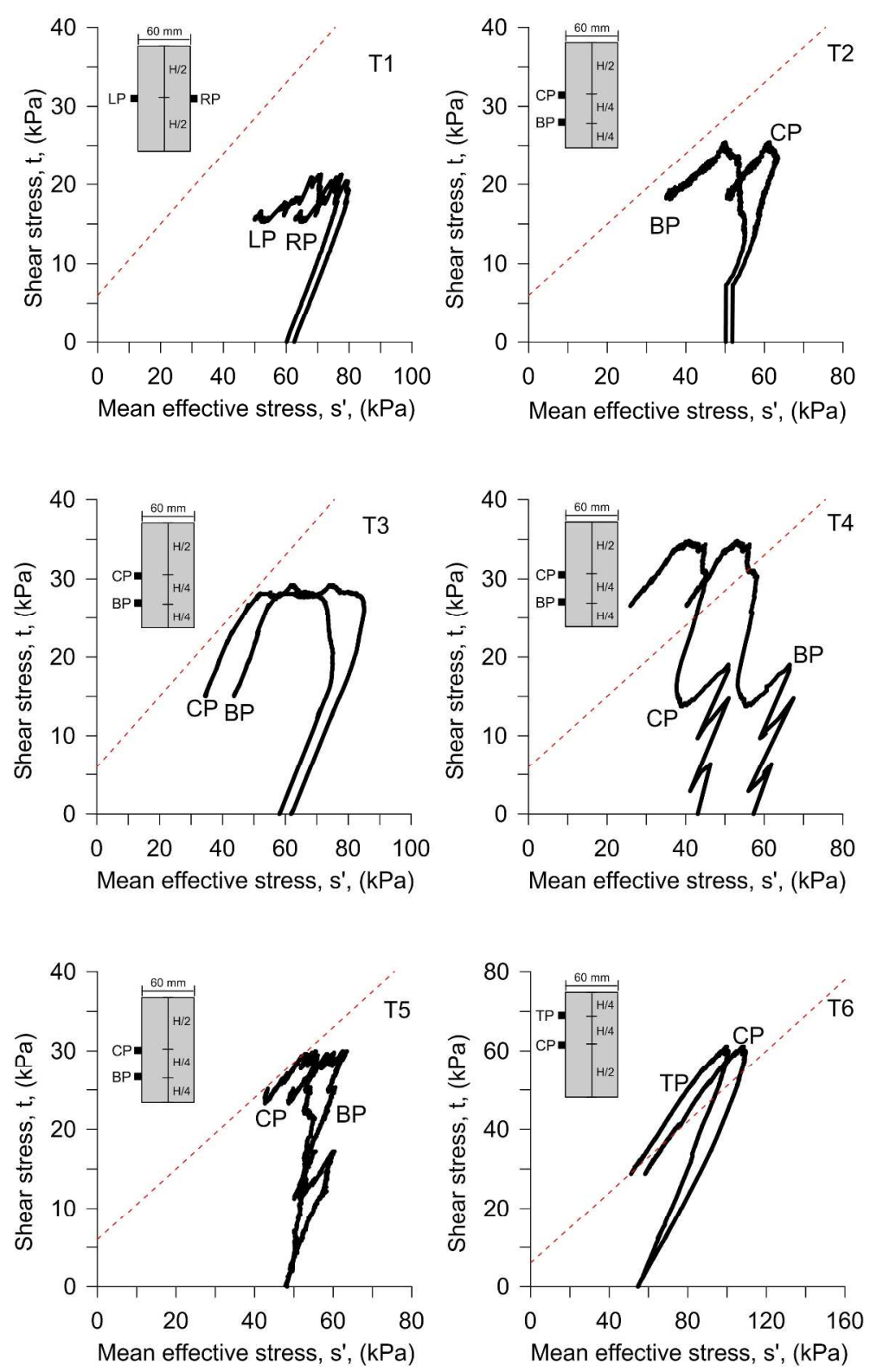

Figure 10. Effective stress paths obtained for the plane strain tests. In this figure, $\mathrm{s}^{\prime}$ represents the mean effective stress $\left(\left(\sigma_{z}{ }^{\prime}+\sigma_{x}{ }^{\prime}\right) / 2\right)$, t denotes the shear stress $\left(\sigma_{z}{ }^{\prime}-\sigma_{x}{ }^{\prime}\right) / 2$, and $\sigma^{\prime}$ are the effective stresses; the subscripts $z$ and $x$ stand for the axial and horizontal direction in the plane of deformation. The dotted line refers to a failure line corresponding to $c=6 \mathrm{kPa}$ and $\varphi=26.5^{\circ}$. The selected $\mathrm{c}$ and $\varphi$ values are typical for quick clays for this site. 

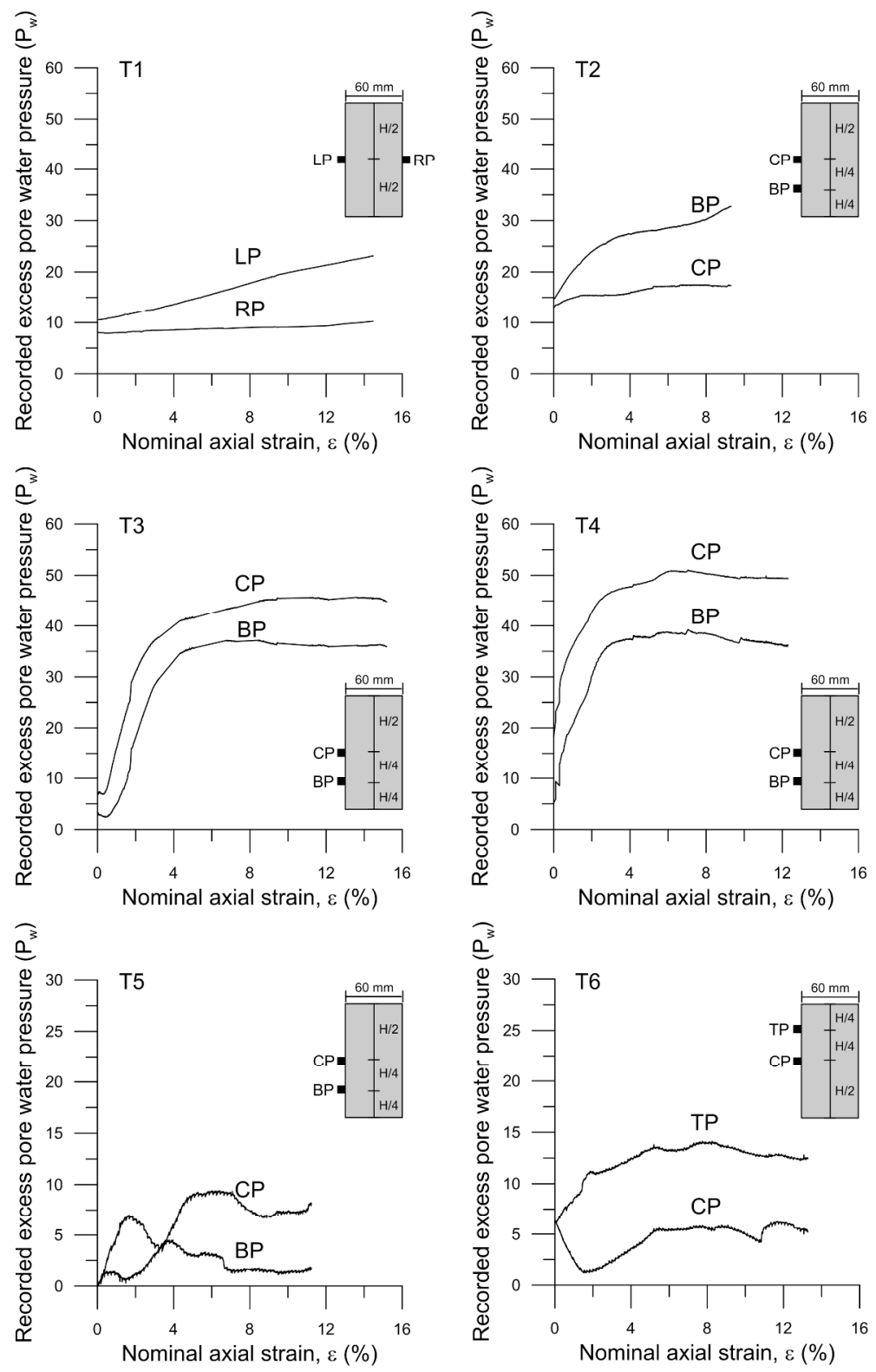

Figure 11. Measured pore water pressure at the probe locations vs relative deformation $(\varepsilon)$ for the plane strain tests. The locations of the probes on the samples are shown. LP, RP, CP, BP, and TP refers to left probe, right probe, central probe, bottom probe and top probe respectively. Here, $\mathrm{H}$ is the sample height which is equal to $120 \mathrm{~mm}$. 


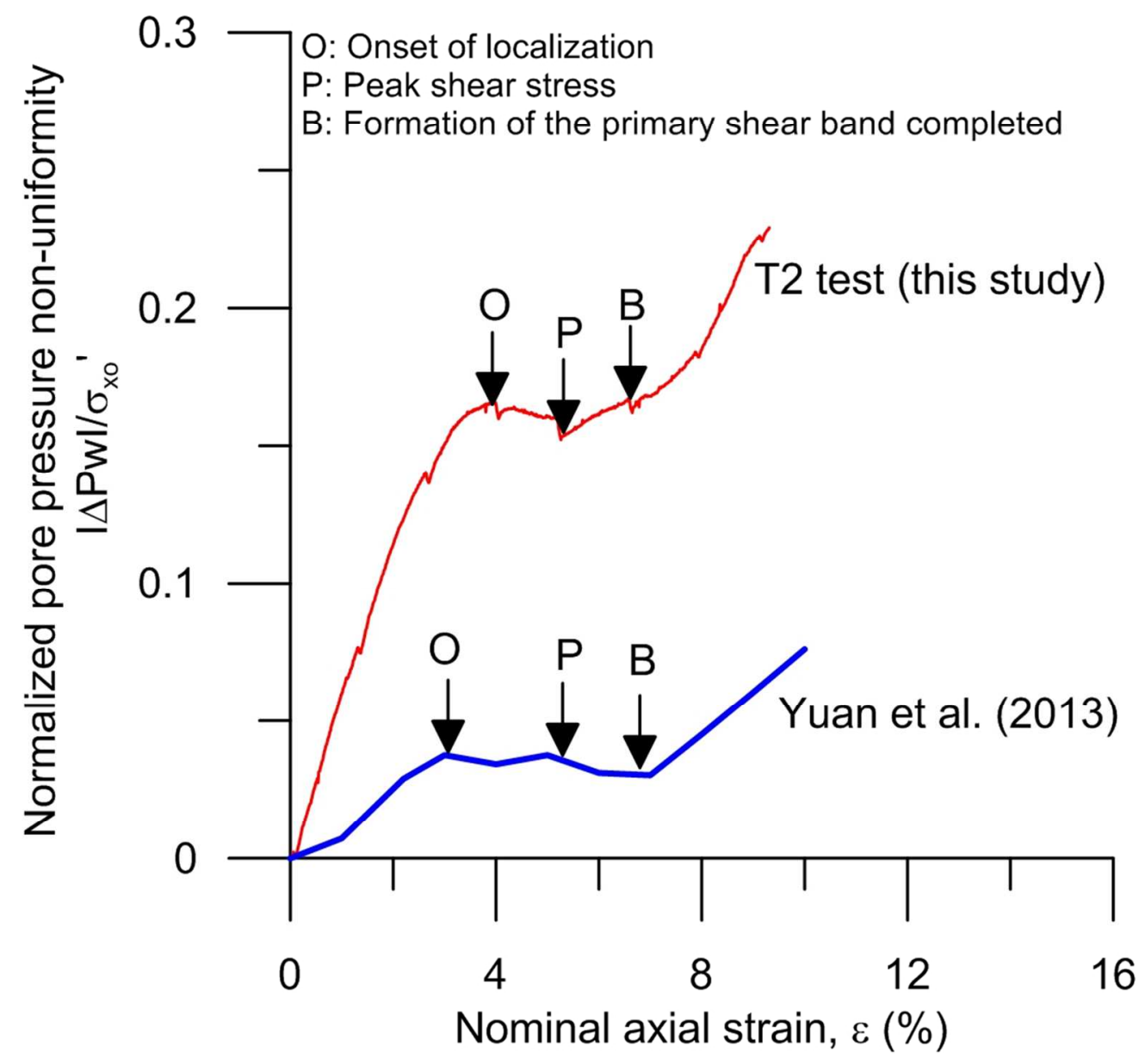

Figure 12. Comparison of pore water pressure non-uniformities observed in quick clay in this study and those observed by Yuan et al. (2013) in Shanghai silty clay. 
Table 1. A summary of different sensitivity scales proposed in the literature.

\begin{tabular}{cc}
\hline Sensitivity $\left(\mathbf{S}_{\mathbf{t}}\right)$ & Classifications \\
\hline 1 & Non-sensitive \\
$1-8$ & $\mathrm{LS}$ \\
$8-16$ & $\mathrm{HS} / \mathrm{ES} / \mathrm{SQ}$ \\
$16-32(30)$ & $\mathrm{Q} / \mathrm{MQ}$ \\
$>32$ & $\mathrm{Q}$ \\
\hline L: low; M: medium; H: high; E: extra; : : sensitive; Q: quick
\end{tabular}


Table 2. Summary of the physical and mechanical properties of tiller quick clay

\begin{tabular}{lc}
\hline Soil Parameters & Values \\
\hline Unit weight, $\gamma,\left[\mathrm{kN} / \mathrm{m}^{3}\right]$ & $18.4-18.7$ \\
Natural water content, $w,[\%]$ & $33-40$ \\
Liquid limit, $w_{L},[\%]$ & $24-26$ \\
Plastic limit, $w_{P},[\%]$ & 18 \\
Plasticity index, $I_{p},[\%]$ & $6-8$ \\
Liquidity index, $I_{L},[-]$ & $1.5-1.8$ \\
Undrained shear strength, $c_{u},[\mathrm{kPa}]$ & $18-25$ \\
Effective frictional angle, $\varphi,[$ degrees] & 26.5 \\
Effective cohesion, $c,[\mathrm{kPa}]$ & 6 \\
Remolded undrained shear strength, $c_{u r},[\mathrm{kPa}]$ & $0.1-0.3$ \\
Sensitivity, $S_{t},[-]$ & $83-180$ \\
Over-consolidation ratio [-] & $1.3-1.6$ \\
\hline
\end{tabular}


Table 3. Testing program

\begin{tabular}{|c|c|c|c|c|}
\hline Tests & $\begin{array}{c}\text { Rate of axial } \\
\text { shortening } \\
{[\mathrm{mm} / \mathrm{min}]}\end{array}$ & $\begin{array}{c}\text { In-situ effective } \\
\text { vertical stress } \\
\sigma_{\mathrm{zo}} \\
{[\mathrm{kPa}]}\end{array}$ & $\begin{array}{l}\text { Selected confining } \\
\text { pressure } *[\mathrm{kPa}] \\
=\mathbf{K}_{\mathbf{o}} \cdot \sigma_{\mathrm{zo}},\end{array}$ & Probe locations $^{\wedge}$ \\
\hline $\mathrm{T} 1$ & 0.06 & 120 & 70 & Left and Right (LP, RP) \\
\hline $\mathrm{T} 2$ & 0.06 & 100 & 60 & Central and Bottom (CP, BP) \\
\hline $\mathrm{T} 3$ & 0.06 & 100 & 65 & Central and Bottom (CP, BP) \\
\hline $\mathrm{T} 4$ & 0.06 & 100 & 63 & Central and Bottom (CP, BP) \\
\hline $\mathrm{T} 5$ & 0.006 & 100 & 60 & Central and Bottom (CP, BP) \\
\hline T6 & 0.006 & 120 & 70 & Central and Top (CP, TP) \\
\hline
\end{tabular}

